\title{
Recent Advances in Catalytic Hydrogenation of Furfural
}

\author{
Yantao Wang 1,2,3, Deyang Zhao ${ }^{2,3}$, Daily Rodríguez-Padrón ${ }^{3,4}$ and Christophe Len ${ }^{2,3, *}$ \\ 1 School of Ressources Environmental \& Chemical Engineering, Nanchang University, \\ Nanchang 330031, China; yantao.wang@chimieparistech.psl.eu \\ 2 Sorbonne Universités, Université de Technologie de Compiègne, Centre de Recherche Royallieu, CS 60319 , \\ F-60203 Compiègne CEDEX, France; deyang.zhao@chimieparistech.psl.eu \\ 3 Chimie ParisTech, PSL University, CNRS, Institute of Chemistry for Life and Health Sciences, \\ 11 rue Pierre et Marie Curie, F-75231 Paris CEDEX 05, France; dailydggs@gmail.com \\ 4 Departamento de Química Orgánica, Universidad de Córdoba, Campus de Rabanales, Edificio Marie \\ Curie (C-3), Ctra Nnal IV-A, km. 396, E-14014 Cordoba, Spain \\ * Correspondence: christophe.len@chimieparistech.psl.eu
}

Received: 31 July 2019; Accepted: 19 September 2019; Published: 24 September 2019

\begin{abstract}
Furfural has been considered as one of the most promising platform molecules directly derived from biomass. The hydrogenation of furfural is one of the most versatile reactions to upgrade furanic components to biofuels. For instance, it can lead to plenty of downstream products, such as (tetrahydro)furfuryl alcohol, 2-methyl(tetrahydro)furan, lactones, levulinates, cyclopentanone(l), or diols, etc. The aim of this review is to discuss recent advances in the catalytic hydrogenation of furfural towards (tetrahydro)furfuryl alcohol and 2-methyl(tetrahydro)furan in terms of different non-noble metal and noble metal catalytic systems. Reaction mechanisms that are related to the different catalytic materials and reaction conditions are properly discussed. Selective hydrogenation of furfural could be modified not only by varying the types of catalyst (nature of metal, support, and preparation method) and reaction conditions, but also by altering the reaction regime, namely from batch to continuous flow. In any case, furfural catalytic hydrogenation is an open research line, which represents an attractive option for biomass valorization towards valuable chemicals and fuels.
\end{abstract}

Keywords: furfural; catalytic hydrogenation; biomass; heterogeneous catalyst; continuous flow

\section{Introduction}

The exploration and development of new, non-fossil carbon energy sources are urgently needed due to the increasing energy consumption and the decreasing reserves of fossil resources and global ecological degradation [1]. In this regards, biomass conversion is a promising way to overcome the dependence of society on fossil hydrocarbons (oil, coal, and gas), especially in fuel production and energy areas [2]. Via bio-refinery, lignocellulose can be converted into relevant chemicals, such as furfural [3-10], 5-hydroxymethylfurfural (HMF) [11-15], and alkyl levulinates [16-20], among others. In particular, furfural has been recognized as a crucial bio-based platform molecule, and therefore, its valorization has been attracting researchers' attention in recent years. As illustrated in Figure 1, several processes, including hydrogenation, oxidation and cyanation, could produce furfural downstream products. Undoubtedly, it can be concluded that the most important and extended application of furfural is focused on its hydrogenation, since ca. $62 \%$ of furfural was industrially used for furfuryl alcohol (FA) production [21]. 


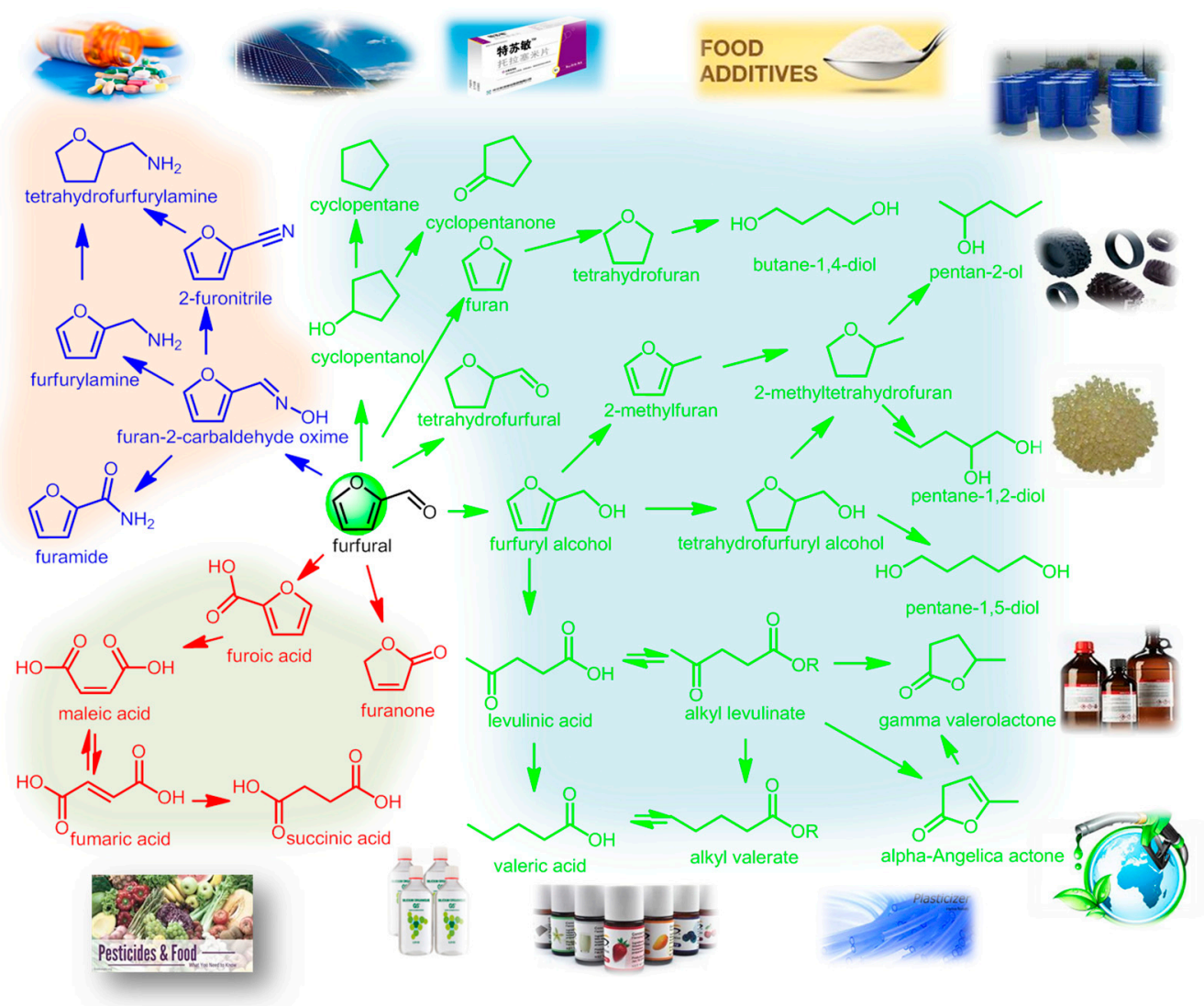

Figure 1. Downstream products of furfural, obtained by hydrogenation (in green), oxidation (in red), cyanation, and other processes (in blue).

FA is a very important monomer for the synthesis of furan resins, which are widely used in thermoset polymer matrix composites, cements, adhesives, coatings, and casting/foundry resins. This molecule is also used as a non-reactive diluent for epoxy resin, a modifier for phenolic and urea resins, an oil well, and a carbon binder. Furthermore, the salt of FA is used in the synthesis of lysine, vitamin C, lubricants, and plasticizers [22,23]. Moreover, it should be highlighted that FA is also an important intermediate for the production of further hydrogenation products (as shown in Scheme 1), such as 2-methylfuran (MF), a potential alternative fuel with better combustion performance and higher Research Octane Number ( $\mathrm{RON}=103)$ than that of gasoline $(\mathrm{RON}=96.8)$ [24]. In other applications, $\mathrm{MF}$ is used in perfume intermediates, chloroquine lateral chains in medical intermediates, and as a raw material for the production of chrysanthemate pesticides [25].

Moreover, tetrahydrofurfuryl alcohol (THFA) can be used as a green solvent in the pharmaceutical industry and, in addition, it constitutes an outstanding intermediate to produce dihydropyran [26], pyridine [27], tetrahydrofuran, and pentan-1,5-diol [28-30]. Particularly, the latest molecule is an important monomer in the plastics industry. Furthermore, 2-methyltetrahydrofuran (MTHF) is quite engaging for its possible applications in organometallic chemistry, as well as in organic reactions that are related to organocatalysis, biotransformations, and biomass processing [31]. 


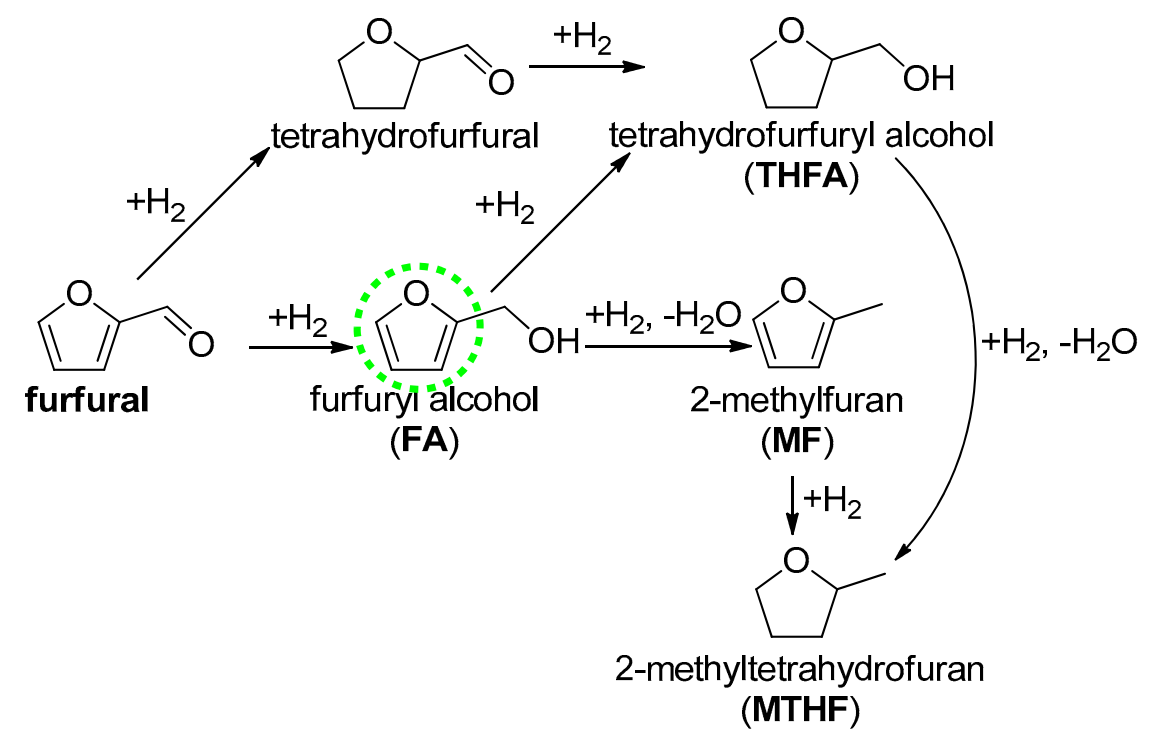

Scheme 1. Illustrative representation of reaction pathways in furfural hydrogenation.

Other downstream products of furfural hydrogenation, such as (tetrahydro)furan [32], tetrahydrofurfural [33], lactones [34-37], levulinates [38,39], cyclopentanone(1) [40-51]. or diols [52-55], could also be employed as fuel additives, solvents, and platform molecules. Numerous studies on furfural hydrogenation have been published due to the attractive and broad range of applications of the aforementioned furfural-based compounds. However, to the best of our knowledge, very limited works have been focused on furfural selective hydrogenation [56-58]. The most recent contribution in this regard was addressed by Yan et al. in 2014, through a critical review. Such work focused on furfural hydrogenation towards different products, such as MF, MTHF, FA, THFA, furan, tetrahydrofuran, as well as various cyclo-products [58]. After 2014, there has been a blank period, in which even when the study of furfural hydrogenation has rapidly increased and emerged into a very dynamic research field, no systematical review has been reported to shine a light on the future of furfural hydrogenation.

Therefore, in the present review, recent advances in catalytic hydrogenation of furfural to (tetrahydro)furfuryl alcohol and 2-methyl(tetrahydro)furan in the latest five years will be discussed. This contribution will be mainly focused on catalytic processes while using different kinds of materials, such as non-noble metal ( $\mathrm{Cu}$ [59-69], Ni [70-80], Co [73,81-83], etc.), and noble metal (Pd [32,33,84-93], $\mathrm{Pt}[49,55,92,94-99], \mathrm{Ru}[84,100-105]$, etc.) based catalysts. Additionally, special attention will be devoted to the possible reaction mechanisms for the different described reactions.

Although it will not be the focus of our main attention, it should be highlighted that furfural valorization via bio-catalytic and electro-catalytic hydrogenation [21,106-112] has also attracted the interest of the scientific community in recent years, being both, emerging environmentally friendly approaches for the selective reduction of multifunctional chemicals.

\section{Non-Noble Metal Catalysts}

Over the past few years, non-noble metal catalysts have attracted much attention due to their comparable properties with noble metal catalysts in both homogeneous and heterogeneous catalysis [113-117]. In particular, furfural hydrogenation has been widely tested while using various non-noble metal catalysts, such as $\mathrm{Cu}, \mathrm{Co}, \mathrm{Ni}$, and $\mathrm{Zr}$, among others. In this section, recent advances in furfural hydrogenation using non-noble metal catalysts will be discussed.

\section{1. $\mathrm{Cu}$ Based Catalysts}

Especially, Cu-based catalysts have been well recognized for its low price, accessibility, and satisfactory hydrogenation selectivity. Therefore, the scientific community has started to move 
towards the use of this metal for catalytic hydrogenation processes. Several examples will be addressed below in order to provide a general panorama in this regard.

For instance, Sun et al. have investigated the morphological effect of non-supported copper nanocrystals on furfural hydrogenation [118]. They found out that $\mathrm{Cu}$ nanowires exhibited three times higher TOF than $\mathrm{Cu}$ nanodisks, suggesting a significant morphology-dependent effect (Figure 2A,B). However, without support, genuine $\mathrm{Cu}$ nanowires gave rise to very limited furfural conversion $(38 \%)$ at $200{ }^{\circ} \mathrm{C}$, even with 30 bar of $\mathrm{H}_{2}$ pressure (Table 1 , entry 1 ).
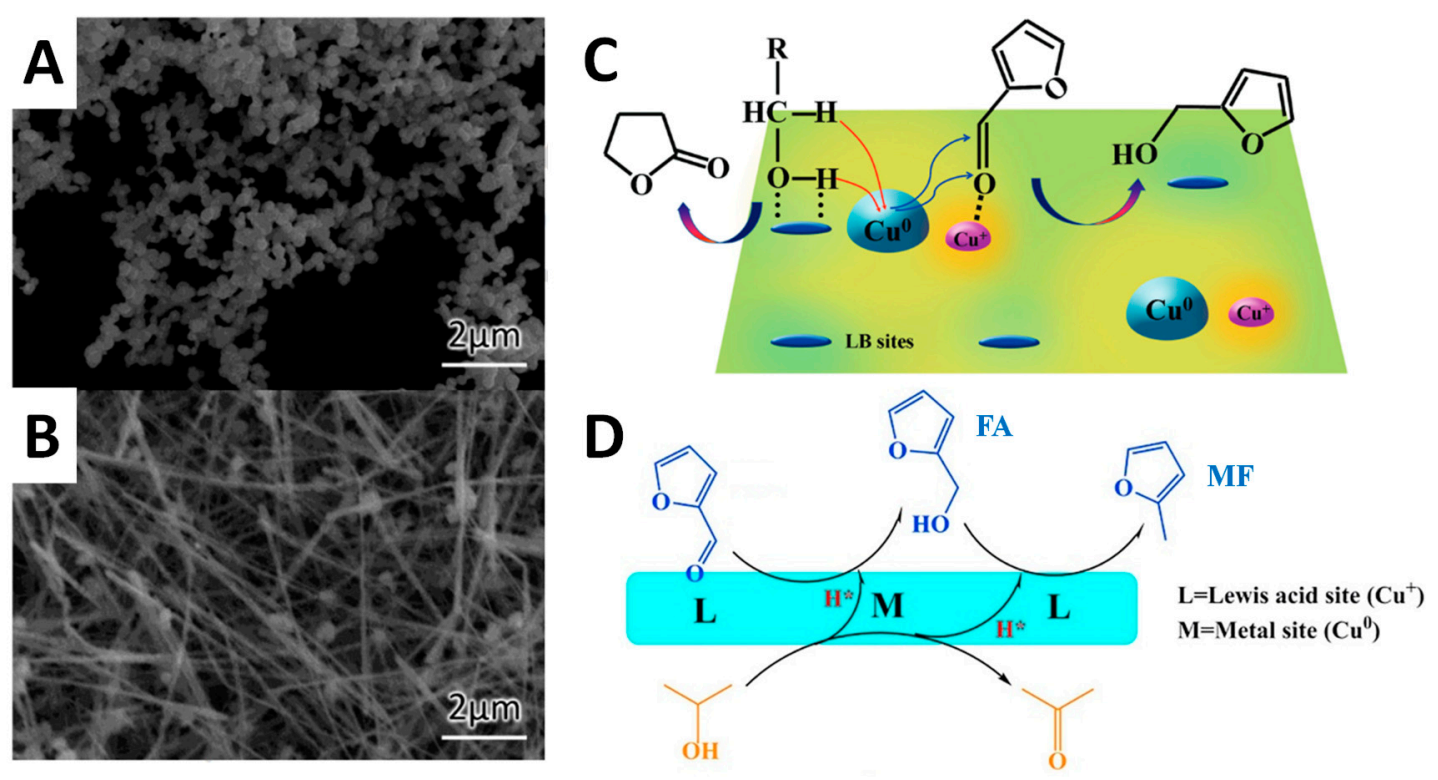

Figure 2. Scanning Electron Microscopy (SEM) images of (A) Cu nanodisk and (B) Cu nanowires, Reprinted with permission from [118]. Copyright 2016 Elsevier. (C) Schematic representation of simultaneous furfural hydrogenation and 1,4-butanediol dehydrogenation using $\mathrm{Cu} / \mathrm{CaAlO}$ based-catalyst, Reprinted with permission from [34]. Copyright 2016 Royal Society of Chemistry. (D) Proposed reaction pathways for transfer hydrogenation of furfural to 2-methylfuran (MF) employing $\mathrm{Cu} / \mathrm{AC}$ catalyst. Adapted with permission from [119]. Copyright 2016 Elsevier.

Furthermore, Wang et al. studied the effect of the acid and basic features of the support on $\mathrm{Cu}$ based catalysts performance [69] with five different supports, namely $\mathrm{ZMS}-5, \mathrm{Al}_{2} \mathrm{O}_{3}, \mathrm{SiO}_{2}, \mathrm{ZnO}$, and $\mathrm{MgO}$. The results showed that the total acidity of the copper modified supports followed the order: $\mathrm{Cu} / \mathrm{ZSM}-5(687.4 \mu \mathrm{mol} / \mathrm{g})>\mathrm{Cu} / \mathrm{Al}_{2} \mathrm{O}_{3}(268.9 \mu \mathrm{mol} / \mathrm{g})>\mathrm{Cu} / \mathrm{SiO}_{2}(200.6 \mu \mathrm{mol} / \mathrm{g})>\mathrm{Cu} / \mathrm{ZnO}(32.2 \mu \mathrm{mol} / \mathrm{g})$ $>\mathrm{Cu} / \mathrm{MgO}(0 \mu \mathrm{mol} / \mathrm{g})$, while the total basicity followed the order: $\mathrm{Cu} / \mathrm{MgO}(312.4 \mu \mathrm{mol} / \mathrm{g})>\mathrm{Cu} / \mathrm{Al}_{2} \mathrm{O}_{3}$ $(115.2 \mu \mathrm{mol} / \mathrm{g})>\mathrm{Cu} / \mathrm{ZnO}(17.2 \mu \mathrm{mol} / \mathrm{g})>\mathrm{Cu} / \mathrm{SiO}_{2}(9.4 \mu \mathrm{mol} / \mathrm{g})>\mathrm{Cu} / \mathrm{ZSM}-5(0 \mu \mathrm{mol} / \mathrm{g})$. It was found that the acid supported catalyst, such as $\mathrm{Cu} / \mathrm{ZSM}-5$, led to a poor mass balance and gave rise to some oligomers as main products. In turn, basic support, such as $\mathrm{Cu} / \mathrm{MgO}$, gave a better mass balance and FA as the main product.

Moreover, $\mathrm{Hu}$ et al. developed novel bifunctional base-metal heterogeneous catalysts $(\mathrm{Cu} / \mathrm{CaAlO})$ for the simultaneous furfural hydrogenation and 1,4-butanediol dehydrogenation under solvent-free conditions and without external $\mathrm{H}_{2}$ supply (Figure 2C) [34]. Inspiringly results of $96 \% \mathrm{FA}$ and $100 \%$ gamma-butyrolactone (GBL) yield was obtained with $\mathrm{Cu} / \mathrm{CaAlO}$ (Table 1, entry 2), and it was found that furfural hydrogenation accelerated 1,4-butanediol dehydrogenation to GBL. Additionally, FA selectivity greatly decreased due to the formation of MF under $\mathrm{H}_{2}$ conditions. The impressive catalytic performance of the catalyst should be ascribed to the existence of defective $\mathrm{Cu}$ NPs, abundant strong Lewis base sites, and $\mathrm{Cu}^{+}$species on the catalyst surface. Identically, the uniform size and well dispersed $\mathrm{Cu}$ nanoparticles on high surface area activated carbon with the suitable proportion of $\mathrm{Cu}^{2+}, \mathrm{Cu}^{0}$, and $\mathrm{Cu}^{+}$was associated with the superior transfer hydrogenation catalytic performance of 
$\mathrm{Cu} / \mathrm{AC}$ catalyst, which offered $92 \%$ of MF yield (Table 1, entry 3) [119]. Zhang et al. also proved that $\mathrm{Cu}^{+} / \mathrm{Cu}^{0}$ are both necessary and active species for the furfural reduction reaction, and that depositing a thin $\mathrm{Al}_{2} \mathrm{O}_{3}$ layer on $\mathrm{CuCr}_{2} \mathrm{O}_{4}{ }^{*} \mathrm{CuO}$ increased the catalyst activity while simultaneously decreasing the activation energy of furfural hydrogenation [120].

Furfural hydrogenation to $\mathrm{FA}$ under microwave irradiations over $\mathrm{Cu} / \mathrm{TiO}_{2}$ as catalyst has been investigated by Romano et al., being the first contribution using pressurized microwave reactors (Figure 3B) [59]. Microwave irradiations offered an unexpected enhancement in FA selectivity to 99\% and a 3-4 fold increase in conversion in comparison to the conventional heating method. Besides, experiments were conducted at relatively mild conditions $\left(125^{\circ} \mathrm{C}\right)$ with $\mathrm{CPME}$ as green solvent, and the catalyst could be reused three times without loss of activity (Table 1, entry 19).

\section{Furfuryl alcohol}

A
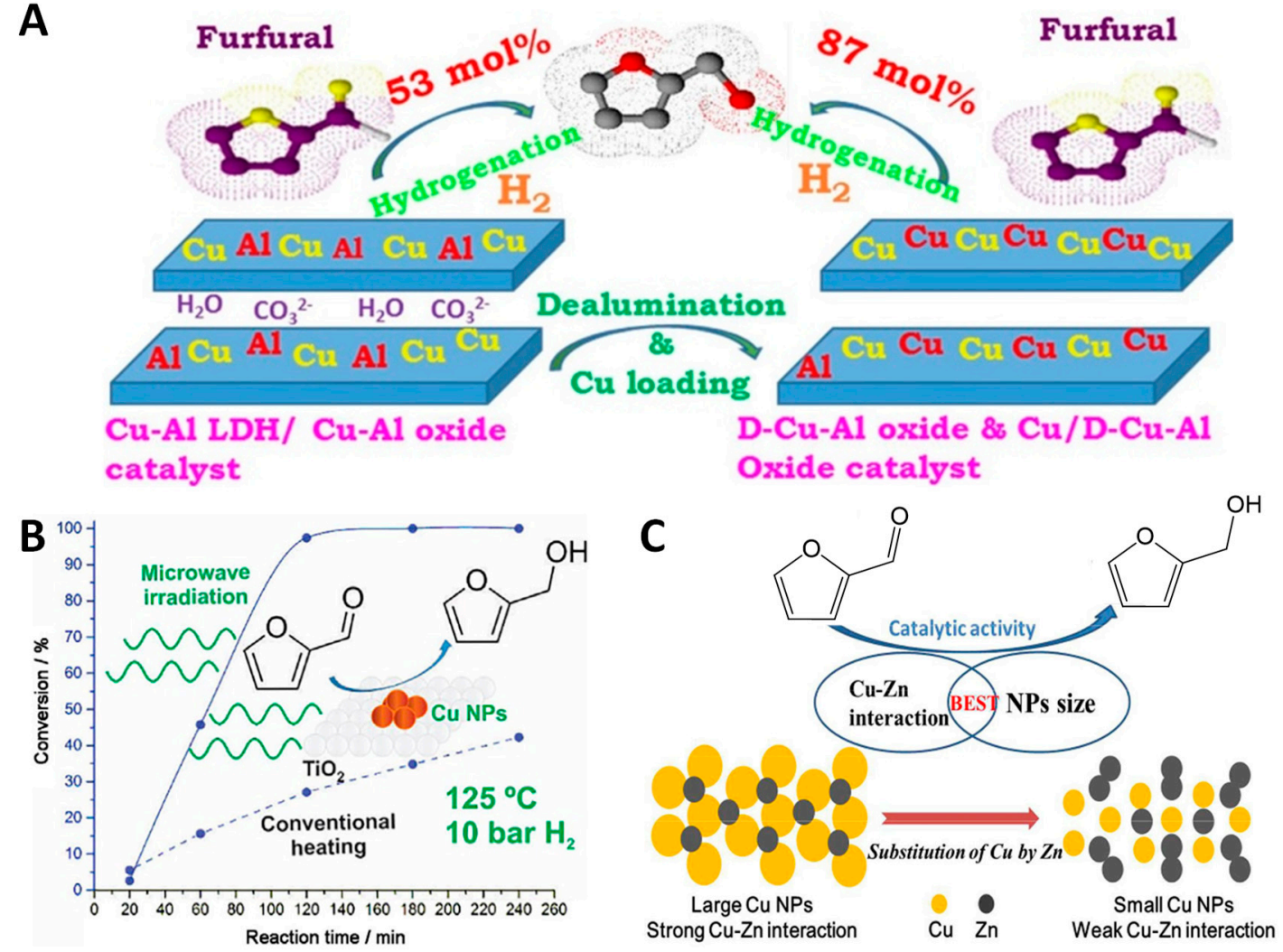

Figure 3. (A) Conversion of furfural to furfuryl alcohol (FA) by using Cu-modified dealuminated layered double hydroxides. Reprinted with permission from [121]. Copyright 2016 Elsevier. (B) Comparison between furfural hydrogenation over $\mathrm{Cu} / \mathrm{TiO}_{2}$ under conventional heating and microwave irradiation. Reprinted with permission from [59]. Copyright 2016 Wiley-VCH. (C) Schematic representation of catalytic furfural hydrogenation towards FA employing $\mathrm{Cu} / \mathrm{ZnO}-\mathrm{Al}_{2} \mathrm{O}_{3}$. Role of $\mathrm{Al}$ components in the dispersion of copper/zinc species. Adapted with permission from [60]. Copyright 2018 Elsevier.

Prakruthi et al. found that $\mathrm{Al}$ deficient $\mathrm{Cu}-\mathrm{Al}$ oxide prepared possesses higher surface area and pore volume. By loading $\mathrm{Cu}(15 \mathrm{wt} \%)$ on dealuminated layered double hydroxides, the catalyst could achieve $77 \%$ FA yield at $220{ }^{\circ} \mathrm{C}$ with $3.6 \mathrm{~h}^{-1} \mathrm{LHSV}$ (Table 1 entry 4) [121]. The obtained catalytic performance could be explained by the new term pore occupancy hydrogenation efficiency factor. 
In addition, Jiménez-Gómez et al. prepared different kinds of $\mathrm{Cu} / \mathrm{ZnO}$ and $\mathrm{Cu} / \mathrm{CeO}_{2}$ catalysts, and investigated their catalytic performance under gas-phase hydrogenation of furfural to FA $[64,122]$. In both cases, best FA yield was around $70 \%$, and the hydrogenation products slightly varied with the time on stream (Table 1, entries 5 and 7). Subsequently, the authors used disordered kerolitic clay formed by kerolite/stevensite mixed layer as catalytic support to disperse $\mathrm{Cu}$-species. In this case, lower selectivity to FA was obtained, and thus the major product was MF [123]. In this regard, the selectivity to FA could be improved by the incorporation of $\mathrm{Ce}$ and $\mathrm{Zn}$ as promoters (Table 1, entry 8). Yang et al. have improved FA yield to $94 \%$ by using $\mathrm{Cu} / \mathrm{ZnO}(\mathrm{Cu} / \mathrm{Zn}=0.8)$ that was prepared via "decrease $\mathrm{pH}^{\prime \prime}$ co-precipitation method (Table 1, entry 6) [65]. The excellent catalyst performance was ascribed to suitable $\mathrm{Cu}$ particle size $(8 \mathrm{~nm})$ and strong metal-support interactions. Jackson et al. have supported $\mathrm{CuO}$ and $\mathrm{CeO}_{2}$ on $\gamma-\mathrm{Al}_{2} \mathrm{O}_{3}$, and then $\mathrm{CuO}$ excess on the catalyst surface was stripped with $\mathrm{HNO}_{3}$ (Table 1, entry 10) [124]. This catalyst could give rise to $85 \%$ FA yield at $175{ }^{\circ} \mathrm{C}$ in the continuous flow regime, which showed higher intrinsic reactivity than the two control catalysts: $\mathrm{Cu} / \mathrm{Al}_{2} \mathrm{O}_{3}$ and copper chromite.

In 2014, Vargas-Hernández et al. have studied FA production from furfural over Cu/SBA-15 as catalyst, however a limited FA yield of $52 \%$ was obtained (Table 1, entry 13) [63]. Afterwards, Srivastava et al. synthesized series $\mathrm{Cu}-\mathrm{Co}$ bimetallic catalysts supported on SBA-15 for furfural hydrogenation to FA [125]. The aforementioned study attained around $80 \%$ yield of FA with $9 \%$ of $\mathrm{MF}$ and $10 \%$ of cyclopentanol. Later on, three different supported bimetallic catalysts $\left(\mathrm{Cu}-\mathrm{Co} / \mathrm{SiO}_{2}\right.$, $\mathrm{Cu}-\mathrm{Co} / \mathrm{H}-\mathrm{ZSM}-5$, and $\mathrm{Cu}-\mathrm{Co} / \gamma-\mathrm{Al}_{2} \mathrm{O}_{3}$ ) were prepared by an impregnation method, and tested for furfural selective hydrogenation to MF [126]. The results indicated that the strong interaction between $\mathrm{Cu}$ and $\mathrm{Co}$ has significant influence on the catalytic performance of bi-metallic catalyst. Acid supports, such as H-ZSM- 5 and $\gamma-\mathrm{Al}_{2} \mathrm{O}_{3}$, are more selective towards MF, which is in accordance with a previous study, where $\mathrm{Cu} / \mathrm{SiO}_{2}$ is more effective towards $\mathrm{MF}$ production $(90 \%$, Table 1 entry 11$)$ than $\mathrm{Cu} / \mathrm{ZnO}$ and $\mathrm{Cu} / \mathrm{Al}_{2} \mathrm{O}_{3}$ due to the synergistic effect between the metal counterpart and the weak acid site [61]. Srivastava et al. have reported an optimization, kinetics, and reaction mechanism study of furfural conversion to MF over $\mathrm{Cu}-\mathrm{Co} / \gamma-\mathrm{Al}_{2} \mathrm{O}_{3}$ [81]. They suggest that $\mathrm{Cu}$ species in the catalyst would dissociate the hydrogen molecule to hydrogen atoms, and then aldehydic oxygen is attracted by the acidic sites of the catalyst, followed by the addition of hydrogen to the carbonyl oxygen atom FA is formed by the further addition of hydrogen to carbonyl carbon atom. It was considered that weak acidic $\mathrm{CoO}_{x}$ phase facilitates the adsorption of FA on the catalyst surface, and promoted FA further hydrogenolysis to MF. The latest process firstly involved the hydrogen atom addition to hydroxyl oxygen atom, releasing one mole of water, and the final addition of hydrogen atom $\left(\mathrm{H}^{-}\right)$ to positive charged carbon atom, which led to the formation of MF. The experimental data could be explained while using Langmuir-Hinshelwood-Hougen-Watson kinetics (see in Scheme 2). Such results indicated that the adsorption of hydrogen and surface reaction were possibly the rate-controlling steps. Dong et al. further improved MF yield to $96 \%$ by performing the reaction at $200{ }^{\circ} \mathrm{C}$ while using $\mathrm{Cu} / \mathrm{SiO}_{2}$ catalyst, prepared by the ammonia evaporation method [127]. They also developed a kind of Cu-phyllosilicate-like catalyst, which could also furnish $96 \%$ MF or $83 \%$ FA yield [68]. In the case of the work developed by Serivastava et al, the best MF selectivity $(78 \%)$ with fully furfural conversion was achieved with $\mathrm{Cu}-\mathrm{Co} / \gamma-\mathrm{Al}_{2} \mathrm{O}_{3}$ at $220^{\circ} \mathrm{C}$ and 40 bar of $\mathrm{H}_{2}$ pressure (Table 1 , entry 17). After optimizing with Taguchi method, the authors were able to improve MF yield to $87 \%$ [81]. Interestingly, $\mathrm{Cu}-\mathrm{Co} / \mathrm{C}-500$ bimetallic catalyst gave rise to $49 \%$ of cyclopentanone as major product with $36 \%$ of $\mathrm{FA}$ at $150{ }^{\circ} \mathrm{C}$ for $3 \mathrm{~h}$ under $\mathrm{H}_{2}$ pressure (5 bar) [128]. Additionally, highly dispersed $\mathrm{Cu}-\mathrm{Co} / \mathrm{C}$ catalyst $(\mathrm{Cu} / \mathrm{Co}=1 / 0.4)$, derived from Co-doped $\mathrm{Cu}-\mathrm{BTC}$ metal-organic frameworks (MOFs) by thermolysis in nitrogen, has showed highly selectivity to FA, and after calcining the catalyst at $500{ }^{\circ} \mathrm{C}$, a $96 \%$ FA yield was achieved at $140{ }^{\circ} \mathrm{C}$ with 30 bar $\mathrm{H}_{2}$ pressure [129].

Moreover, furfural transfer hydrogenation over monometallic and bimetallic $\mathrm{Cu}-\mathrm{Ni}$ catalysts supported on $\mathrm{Al}_{2} \mathrm{O}_{3}$ has been investigated by Zhang et al. [130]. It was found that furfuryl ether outcomes as major by-product by using $\mathrm{Cu} / \mathrm{Al}_{2} \mathrm{O}_{3}$ catalyst, and $\mathrm{Ni} / \mathrm{Al}_{2} \mathrm{O}_{3}$ material results 
in ring-opening products, while $\mathrm{Cu}-\mathrm{Ni} / \mathrm{Al}_{2} \mathrm{O}_{3}$ bimetallic catalysts (especially with $\mathrm{Cu} / \mathrm{Ni}=1 / 2$ ) showed improved activity towards the production of MF and MTHF. Under optimal conditions, $65 \%$ yield of MF and $18 \%$ yield of MTHF were achieved at $230{ }^{\circ} \mathrm{C}$ for $4 \mathrm{~h}$. Remarkably, reusability studies displayed that, after the forth reuse cycle of $\mathrm{Cu}-\mathrm{Ni} / \mathrm{Al}_{2} \mathrm{O}_{3}$ catalytic system, MF yield only decreased $5 \%$. This report is consistent with the study of Srivastava [131] who reported that the incorporation of $\mathrm{Ni}$ with $\mathrm{Cu}$ supported on $\mathrm{Al}_{2} \mathrm{O}_{3}$ increased MF yield from $51 \%$ to $82 \%$. Conversely, Pang et al. found that a small amount of $\mathrm{Ni}$ addition on $\mathrm{Cu} / \mathrm{Al}_{2} \mathrm{O}_{3}$ indeed improved catalytic activity, but slightly decreased the selectivity to MF [132]. Besides, it was revealed that $\mathrm{C} 18$ thiolate-modified $\mathrm{Cu}-\mathrm{Ni}$ bimetallic catalyst could increase both reaction activity and hydrogenation selectivity. By adding formic acid as co-hydrogen donors, Fu et al. achieved $92 \%$ MF yield with $10 \% \mathrm{Cu}-10 \% \mathrm{Ni} / \mathrm{Al}_{2} \mathrm{O}_{3}$ (Table 1 entry 21) [133]. Interestingly, CuNi alloy catalyst offered $95 \%$ of THFA yield with ethanol as solvent, while the major product was FA by using methanol as solvent [134]. At similar conditions, bimetallic catalyst $\mathrm{Cu}-\mathrm{Ni} / \mathrm{CNTs}$ exhibit similar catalytic performance, as compared to the aforementioned $\mathrm{Cu}-\mathrm{Ni} / \mathrm{MgAlO}$ alloy, and attained $90 \%$ yield towards THFA at mild condition $\left(130{ }^{\circ} \mathrm{C}\right.$ and 40 bar $\mathrm{H}_{2}$ pressure for $10 \mathrm{~h})$ [79].

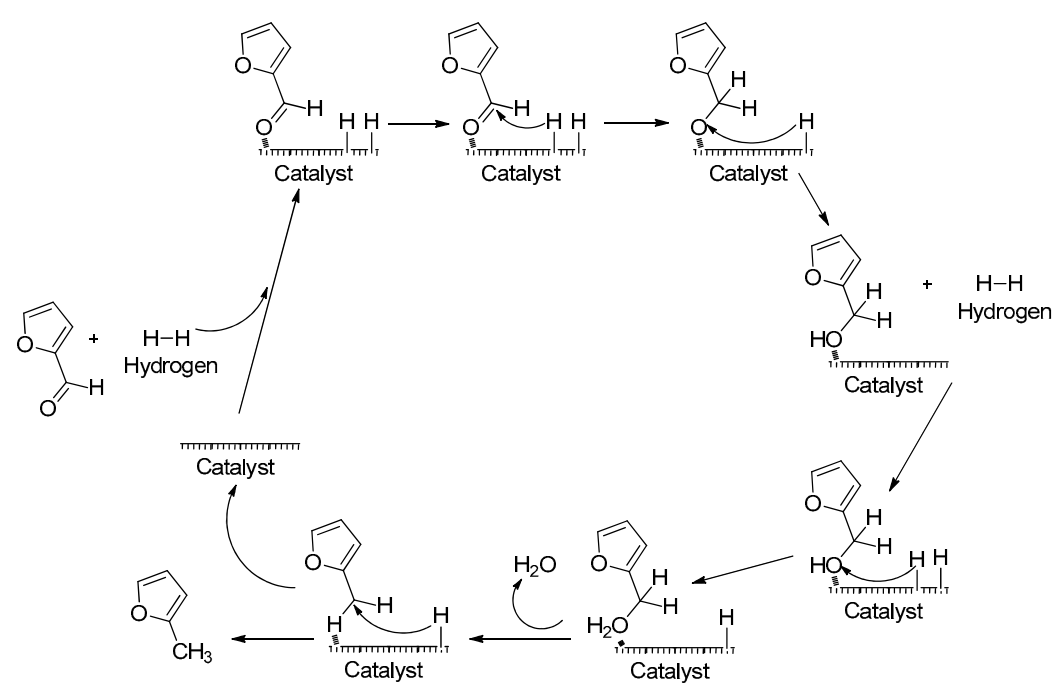

Scheme 2. Langmuir-Hinshelwood-Hougen-Watson type of reaction mechanism for the hydrogenation of furfural to MF. Adapted from Srivastava et al. [81].

Yang et al. investigated the effect of $\mathrm{Al}$ species addition on $\mathrm{Cu} / \mathrm{ZnO}$ catalytic activity [60]. It was found that the constructed $\mathrm{Cu} / \mathrm{ZnO}-\mathrm{Al}_{2} \mathrm{O}_{3}$ catalyst could improve furfural conversion from $85 \%$ to $96 \%$ at $120{ }^{\circ} \mathrm{C}$ with high FA selectivity (96\%) in comparison with the $\mathrm{Cu} / \mathrm{ZnO}$ catalyst. It was confirmed that the role of $\mathrm{Al}$ components was to act as both structural and electronic promoter, thus improving the dispersion of copper/zinc species and hindering $\mathrm{Cu}-\mathrm{ZnO}$ interaction of the aurichalcite derived catalysts (Figure 3C). Similarly, $\mathrm{Cu} / \mathrm{MgO}-\mathrm{Al}_{2} \mathrm{O}_{3}$ has been also tested as an efficient catalyst for furfural transfer hydrogenation to FA under near-critical isopropanol (Table 1, entry 29) [62]. Even at milder conditions $\left(150^{\circ} \mathrm{C}\right), \mathrm{Cu}-\mathrm{Mg}$-Al catalyst that was prepared by co-precipitation method showed $100 \%$ selectivity to FA with fully furfural conversion [66].

Furthermore, Zhang et al. have studied the selective transfer hydrogenation of furfural over hydrotalcite-derived copper catalysts while using methanol as hydrogen donor [135]. The copper catalyst showed excellent transfer hydrogenation selectivity towards FA by giving a FA yield of $94 \%$ at $200{ }^{\circ} \mathrm{C}$, while such catalyst activated with $\mathrm{H}_{2}$ (Cu-Al-A, Table 1 , entry 24 ) notably achieved $94 \% \mathrm{MF}$ yield at $240{ }^{\circ} \mathrm{C}$. These studies stated that valence of active $\mathrm{Cu}$ species, catalyst acidity, and reaction temperature played an important role in product selectivity. 
Table 1. Furfural hydrogenation over $\mathrm{Cu}$-based catalysts.

\begin{tabular}{|c|c|c|c|c|c|c|c|c|c|c|c|}
\hline \multirow{2}{*}{ Entry } & \multirow{2}{*}{ Catalyst } & \multirow{2}{*}{ H Source } & \multirow{2}{*}{ Solvent } & \multirow{2}{*}{ Temperature $\left({ }^{\circ} \mathrm{C}\right)$} & \multirow{2}{*}{ Time (h) } & \multirow{2}{*}{ Pressure (bar) } & \multicolumn{4}{|c|}{ Yield (\%) } & \multirow{2}{*}{ Ref. } \\
\hline & & & & & & & FA & MF & THFA & MTHF & \\
\hline 1 & Cu nanowire & $\mathrm{H}_{2}$ & 1,4-dioxane & 200 & 1.5 & 30 & $>33$ & - & - & - & [118] \\
\hline 2 & $\mathrm{Cu} / \mathrm{CaAlO}$ & 1,4-BDO & - & 210 & $1.8^{a}$ & 1 & 96 & - & - & - & [34] \\
\hline 3 & $\mathrm{Cu} / \mathrm{AC}$ & $\mathrm{i}-\mathrm{PrOH}$ & $\mathrm{i}-\mathrm{PrOH}$ & 200 & 5 & 20 & 8 & 92 & - & - & [119] \\
\hline 4 & $\mathrm{Cu} / \mathrm{CaAlO}$ & $\mathrm{H}_{2}$ & - & 220 & $6^{a}$ & - & 77 & - & - & - & [121] \\
\hline 5 & $\mathrm{Cu} / \mathrm{ZnO}$ & $\mathrm{H}_{2}$ & CPME & 190 & 1 & - & 70 & - & - & - & [122] \\
\hline 6 & $\mathrm{Cu} / \mathrm{ZnO}$ & $\mathrm{H}_{2}$ & - & 120 & $0.435^{a}$ & - & 94 & 0 & - & - & [65] \\
\hline 7 & $\mathrm{Cu} / \mathrm{CeO}_{2}$ & $\mathrm{H}_{2}$ & CPME & 190 & 1 & - & 71 & 6 & - & - & [64] \\
\hline 8 & $\mathrm{Cu} /$ kerolitic clay & $\mathrm{H}_{2}$ & - & 210 & - & - & 32 & 48 & - & - & [123] \\
\hline 9 & $\mathrm{Cu}-\mathrm{CeO}_{2} /$ kerolitic clay & $\mathrm{H}_{2}$ & - & 190 & 5 & - & 81 & - & - & - & [123] \\
\hline 10 & $\mathrm{CuO}-\mathrm{CeO}_{2} / \mathrm{g}-\mathrm{Al}_{2} \mathrm{O}_{3}$ & $\mathrm{H}_{2}$ & - & 175 & 5 & 5 & 85 & 4 & - & - & [124] \\
\hline 11 & $\mathrm{Cu} / \mathrm{SiO}_{2}$ & $\mathrm{H}_{2}$ & - & 220 & $5^{a}$ & 1 & 2 & 90 & - & - & [61] \\
\hline 12 & $\mathrm{Cu} /$ phyllosilicate & $\mathrm{H}_{2}$ & - & 200 & $5^{a}$ & - & 2 & 87 & - & 1 & [68] \\
\hline 13 & $\mathrm{Cu} / \mathrm{SBA}-15$ & $\mathrm{H}_{2}$ & CPME & 170 & 5 & - & 52 & 2 & - & - & [63] \\
\hline 14 & $\mathrm{Cu}-\mathrm{Co} / \mathrm{SBA}-15$ & $\mathrm{H}_{2}$ & $\mathrm{i}-\mathrm{PrOH}$ & 170 & 4 & 20 & 80 & 9 & - & - & [125] \\
\hline 15 & $\mathrm{Cu}-\mathrm{Co} / \mathrm{SiO}_{2}$ & $\mathrm{H}_{2}$ & $\mathrm{i}-\mathrm{PrOH}$ & 200 & 4 & 40 & 53 & 27 & 5 & 0 & [81] \\
\hline 16 & $\mathrm{Cu}-\mathrm{Co} / \mathrm{H}-\mathrm{ZSM}-5$ & $\mathrm{H}_{2}$ & $\mathrm{i}-\mathrm{PrOH}$ & 200 & 4 & 40 & 28 & 54 & 15 & 2 & [81] \\
\hline 17 & $\mathrm{Cu}-\mathrm{Co} / \mathrm{Al}_{2} \mathrm{O}_{3}$ & $\mathrm{H}_{2}$ & $\mathrm{i}-\mathrm{PrOH}$ & 220 & 4 & 40 & 11 & 78 & 10 & 1 & [81] \\
\hline 18 & $\mathrm{Cu}-\mathrm{Co} / \mathrm{C}$ & $\mathrm{H}_{2}$ & $\mathrm{EtOH}$ & 140 & 1 & 30 & 96 & - & - & - & [129] \\
\hline 19 & $\mathrm{Cu} / \mathrm{TiO}_{2}$ & $\mathrm{H}_{2}$ & CPME & 125 & 3 & 10 & 99 & 1 & 0 & 0 & [59] \\
\hline 20 & $\mathrm{Cu}-\mathrm{Ni}_{2} / \mathrm{Al}_{2} \mathrm{O}$ & $\mathrm{i}-\mathrm{PrOH}$ & $\mathrm{i}-\mathrm{PrOH}$ & 230 & 4 & - & 0 & 65 & 5 & 18 & [130] \\
\hline 21 & $\mathrm{Cu}-\mathrm{Ni} / \mathrm{Al}_{2} \mathrm{O}_{3}$ & $\mathrm{HCOOH}$ & $\mathrm{i}-\mathrm{PrOH}$ & 210 & 7 & - & 2 & 92 & - & - & [133] \\
\hline 22 & $\mathrm{Cu}-\mathrm{Ni} / \mathrm{MgAlO}$ & $\mathrm{H}_{2}$ & $\mathrm{EtOH}$ & 150 & 3 & 40 & 0 & - & 95 & - & [134] \\
\hline 23 & Cu-Ni/CNTs & $\mathrm{H}_{2}$ & $\mathrm{EtOH}$ & 130 & 10 & 40 & 0 & - & 90 & - & [79] \\
\hline 24 & $\mathrm{Cu}-\mathrm{Al}$ & $\mathrm{MeOH}$ & $\mathrm{MeOH}$ & 200 & 2.5 & 10 & 94 & - & - & - & [135] \\
\hline 25 & $\mathrm{Cu}-\mathrm{Al}-\mathrm{A}$ & $\mathrm{MeOH}$ & $\mathrm{MeOH}$ & 240 & 1.5 & 10 & - & 94 & - & - & [135] \\
\hline 26 & $\mathrm{Cu}-\mathrm{Fe}$ & $\mathrm{H}_{2}$ & Octane & 220 & 14 & 90 & 42 & 51 & - & - & [25] \\
\hline 27 & $\mathrm{Cu}-\mathrm{Fe} / \mathrm{Al}_{2} \mathrm{O}_{3}$ & $\mathrm{H}_{2}$ & - & 175 & $1^{a}$ & 1 & 92 & 1 & - & - & [136] \\
\hline 28 & $\mathrm{Cu} / \mathrm{ZnO}-\mathrm{Al}_{2} \mathrm{O}_{3}$ & $\mathrm{H}_{2}$ & - & 120 & $5^{a}$ & 1 & 92 & 3 & - & - & [60] \\
\hline 29 & $\mathrm{Cu} / \mathrm{MgO}-\mathrm{Al}_{2} \mathrm{O}_{3}$ & i-PrOH & $\mathrm{i}-\mathrm{PrOH}$ & 210 & 1 & - & 89 & - & - & - & [62] \\
\hline 30 & $\mathrm{Cu}-\mathrm{Mg}-\mathrm{Al}$ & $\mathrm{i}-\mathrm{PrOH}$ & $\mathrm{i}-\mathrm{PrOH}$ & 150 & 6 & - & 0 & - & - & - & [66] \\
\hline
\end{tabular}

${ }^{a}$ LHSV in $\mathrm{h}^{-1}$. 
A series of non-supported $\mathrm{Cu}-\mathrm{Fe}$ catalysts were prepared by Yan and Chen and tested for furfural hydrogenation to MF [25]. They got $51 \%$ of MF yield at $220{ }^{\circ} \mathrm{C}$ for $14 \mathrm{~h}$ under 90 bar of $\mathrm{H}_{2}$ pressure (Table 1, entry 26). The promoting effect of $\mathrm{Fe}$ on $\mathrm{Cu}$ catalyst performance was also studied by Manikandan et al. [136]. $\mathrm{Cu}-\mathrm{Fe} / \mathrm{Al}_{2} \mathrm{O}_{3}$ catalyst, with $10 \mathrm{wt} \%$ of $\mathrm{Fe}$, exhibited an excellent activity that led to high furfural conversion $(>93 \%)$ and FA selectivity $(>98 \%)$ under mild reaction conditions (Table 1 , entry 27). The high activity of $\mathrm{Cu}-\mathrm{Fe} / \mathrm{Al}_{2} \mathrm{O}_{3}$ material could be attributed to the synergy between $\mathrm{Cu}$ and $\mathrm{Fe}$, and to the existence of oxygen vacancies in the Fe oxide system. Notably, the bimetallic catalyst showed superior stability after $24 \mathrm{~h}$ on stream.

As a short conclusion, Cu-based catalysts could achieve selective hydrogenation of furfural by appropriately choosing supports, solvents, or incorporating other metals. It can be noticed that the acidic and basic sites of the support play the most crucial role in furfural hydrogenation selectivity (acidic sites benefiting to MF production, basic sites resulting to FA), followed by the type of solvent (protic or aprotic) and metal incorporated (Ce, $\mathrm{Co}$, or $\mathrm{Ni}$, etc.).

\subsection{Co, Ni Based Catalyst}

$\mathrm{Co}$ and $\mathrm{Ni}$ are also well-recognized low-cost and high activity non-noble metals, which have been widely used for catalysts preparation. As we discussed in the last section, both of the metals have been introduced with $\mathrm{Cu}$ forming bimetallic catalytic systems. Most of these materials have showed improved catalytic activities in comparison with mono-metallic catalysts. Previous reports suggest that sole Co based catalysts displayed low activity at low temperature and low selectivity at high temperature [82]. Nonetheless, Audemar et al. have recently demonstrated that monometallic Co/SBA-15 catalyst could reach a FA selectivity of $96 \%$ from furfural hydrogenation (Table 2, entry 1 ), while the catalyst stability analysis revealed that continuous Co leaching occurred, which led to the decrease of the catalytic activity [137].

It is worth mentioning that Lee et al. developed $\mathrm{Co} / \mathrm{TiO}_{2}$ catalyst, founding that cobalt particles were covered by a $\mathrm{TiO}_{\mathrm{y}}$ layer after high temperature calcination and reduction treatments (Figure 4A) [138]. No leaching or cobalt particles aggregations were observed, even after $105 \mathrm{~h}$ time of reaction. The excellent catalytic performance (95\% FA yield, Table 2, entry 2) could be possibly associated with the $\mathrm{TiO}_{\mathrm{y}}$ overcoat on the cobalt-based material and the relative mild reaction conditions $\left(80^{\circ} \mathrm{C}\right)$. Very recently, Gong and Jiang have synthesized two kinds of Co based catalysts while using $N$-doped materials as supports [73,82]. In particular, Jiang et al. have synthesized a Co based catalyst using nitrogen-doped porous carbon materials (CPNs) as support (Figure 4B), which gave rise to a comparable FA yield of $98 \%$, albeit with relatively higher reaction temperature $\left(180^{\circ} \mathrm{C}\right)$ [82]. Gong et al. developed a facile one-pot pyrolysis approach using melamine as carbon and nitrogen source to fabricate Co nanoparticles embedded in bamboo-like $\mathrm{N}$-doped carbon nanotubes (named as Co/NCNTs) (Figure 4D-F) [73]. This catalyst showed quite high selectivity to FA at low temperature $\left(100 \%\right.$ selectivity at $\left.\mathrm{T}=60-100{ }^{\circ} \mathrm{C}\right)$. In turn, by increasing the temperature up to $130{ }^{\circ} \mathrm{C}$, further hydrogenation and rearrangement will occur producing cyclopentanone as the main product. Interestingly, THFA with $100 \%$ yield was detected as the final product when using Ni/NCNTs as catalyst at similar reaction conditions (Table 2, entry 5). Therefore, this result suggested that $\mathrm{Ni}$ could lead to deeper hydrogenation, in comparison with Co species. The aforementioned data is consistent with the results of $\mathrm{Su}$ et al., who prepared carbon-embedded $\mathrm{Ni}(\mathrm{Ni} / \mathrm{C})$ catalyst by direct thermal decomposition of Ni-MOF (Figure 4C) [70]. Such contribution reports $100 \%$ THFA yield at $120^{\circ} \mathrm{C}$ in $2 \mathrm{~h}$ with 10 bar $_{2}$ (Table 2, entry 6). As mentioned above, bimetallic catalyst $\mathrm{Cu}-\mathrm{Ni} / \mathrm{CNTs}$ exhibited good selectivity to THFA (90\%, Table 1, entry 23), in fact, Liu et al. also demonstrated that Ni/CNTs catalysts with $\mathrm{Ni}$ content $\geq 10 \%$ have similar or even better selectivity to THFA [79]. 

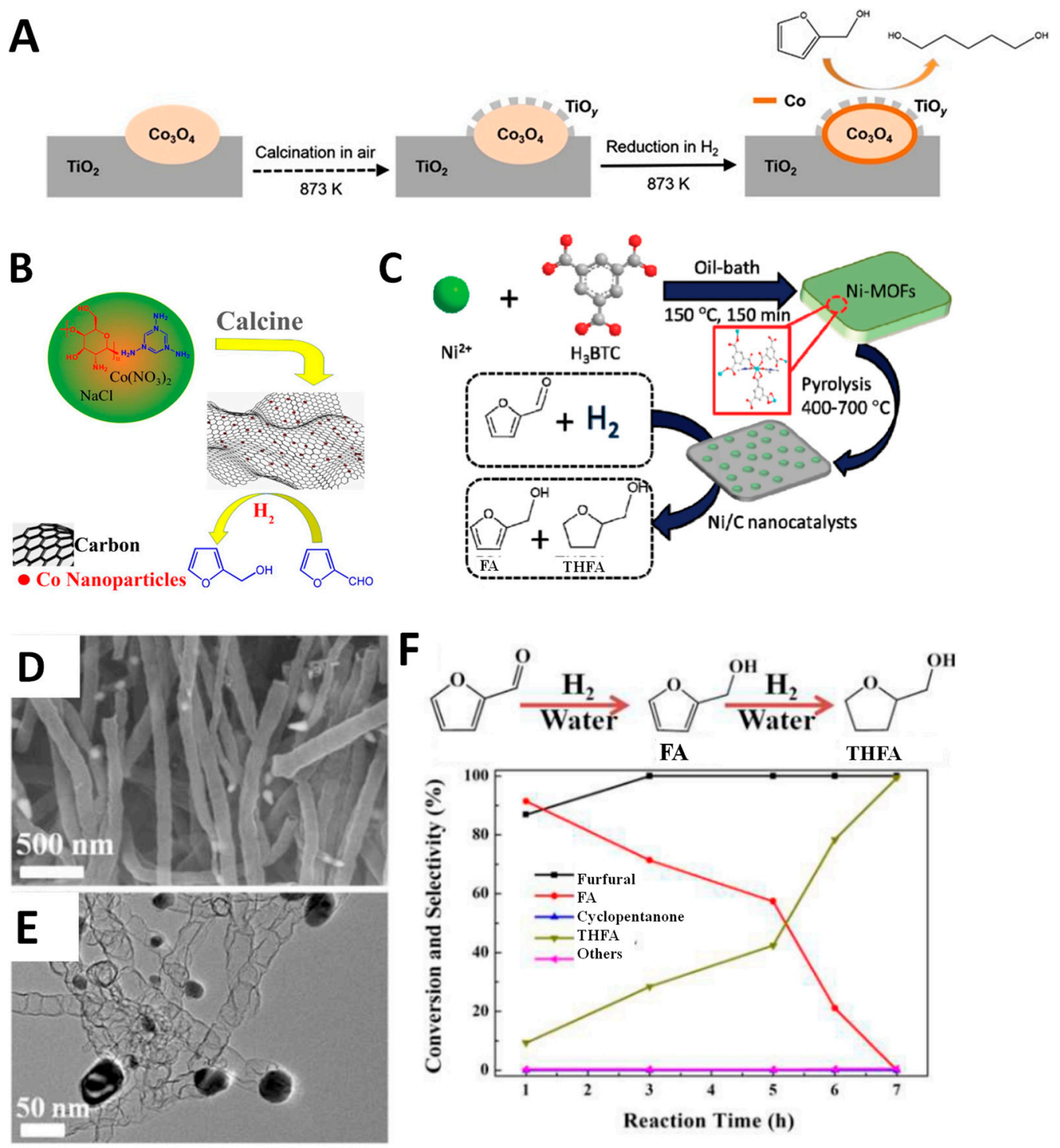

Figure 4. (A) Schematic illustration of the synthetic approach for $\mathrm{Co} / \mathrm{TiO}_{2}$ catalyst and its application in furfural hydrogenation. Reprinted with permission from [138]. Copyright 2015 Elsevier. (B) Co based catalyst over nitrogen-doped porous carbon support for selective hydrogenation of furfural to FA. Reprinted with permission from [82]. Copyright 2018 Elsevier. Ni Nanoparticles Encapsulated in N-Doped Carbon Nanotubes, (C) Synthesis of Ni/C catalysts for hydrogenation of furfural to THFA. Reprinted with permission from [70]. Copyright 2017 Royal Society of Chemistry. (D) SEM image, (E) TEM image and (F) effect of reaction time on the hydrogenation of furfural. Reprinted with permission from [73]. Copyright 2018 Royal Society of Chemistry.

Furthermore, Ni-based catalysts supported on $\mathrm{Al}_{2} \mathrm{O}_{3}$ modified with various alkaline earth metals $(\mathrm{Mg}, \mathrm{Ca}, \mathrm{Sr}, \mathrm{Ba})$ have been reported by Yang at al. It was found that $\mathrm{Ni} / \mathrm{Ba}-\mathrm{Al}_{2} \mathrm{O}_{3}$ was the most efficient catalytic system, with improved THFA selectivity in comparison with the unmodified alumina (from $16 \%$ with $\mathrm{Ni} / \mathrm{Al}_{2} \mathrm{O}_{3}$ to $99 \%$ ) at the same reaction conditions. The presence of alkaline earth metals results in a decrease of $\mathrm{NiAl}_{2} \mathrm{O}_{4}$ species that lead to the increment of the hydrogenation efficiency [71].

Notably, most of studies has indicated that lower reaction temperature favors FA production, and higher reaction temperature will result in a higher selectivity to THFA. In turn, some works have reported divergent results. For instance, Kotbagi et al. found out that furfural was selectively hydrogenated to FA at $200{ }^{\circ} \mathrm{C}$ over $\mathrm{Ni}$ supported on $\mathrm{N}$-doped hierarchically porous carbon catalyst (Table 2, entry 8) [74]. Jeong et al. noticed that $\mathrm{Ni} / \mathrm{SiO}_{2}$ and Raney $\mathrm{Ni}$ have competitive selectivity 
to FA and THFA at $110{ }^{\circ} \mathrm{C}$ under 30 bar $\mathrm{H}_{2}$. Specially, in the aforementioned contribution, the $\mathrm{Ni}$ nanoparticles catalysts capped with organic molecules were successfully developed and employed in the selective furfural hydrogenation to FA with a maximum yield of $96 \%$ [78]. Xu et al. also noticed that Raney Ni could gave rise to various products by hydrogenation/decarboxylation or rearrangement [75]. Authors also concluded that the additives have great effect on the product distribution. Interestingly, Gong et al. communicated that an enhanced catalytic performance of furfural selective hydrogenation could be accomplished while using sulfonated activated carbon supported Ni catalyst [80]. As it has been shown in Table 2, the reaction performed at $60{ }^{\circ} \mathrm{C}$, employing $\mathrm{Ni} / \mathrm{AC}-\mathrm{SO}_{3} \mathrm{H}$ catalyst, could be considered as the best result, with a $100 \%$ of FA yield, while at $100{ }^{\circ} \mathrm{C}$ led to THFA formation, in accordance with previous report with Ni/NCNTs catalyst [73]. More importantly, the conversion of transfer hydrogenation of furfural to FA can also reach almost $100 \%$ yield under optimal conditions $\left(140{ }^{\circ} \mathrm{C}, 4 \mathrm{~h}\right.$, Table 2 , entries 10 and 12$)$.

Manikandan et al. investigated surface synergistic effect on the performance of Ni-based hydrotalcite derived catalysts with different $\mathrm{Ni}-\mathrm{Mg}$-Al ratio, founding that $\mathrm{Ni}_{2} / \mathrm{MgAl}$ could give $92 \% \mathrm{FA}$ yield at $180^{\circ} \mathrm{C}$ [77]. Such results have demonstrated that the incorporation of $\mathrm{Mg}$ significantly enhances the Ni-support interaction, Ni dispersion, and catalytic performance. Analogously, Sulmonetti et al. synthesized different nickel mixed metal oxides that were derived from layered double hydroxides containing $\mathrm{Ni}-\mathrm{Mg}-\mathrm{Al}$ and $\mathrm{Ni}-\mathrm{Co}-\mathrm{Al}$. In this case, a maximum of $70 \% \mathrm{FA}$ with $10 \%$ THFA was yielded [139].

On the other hand, Ni-based catalyst, such as Ni/Cl, could be used to produce MTHF, and Ni-Fe/C bimetallic catalyst, giving rise to MF as the main product with high pressure conditions (Table 2, entries 14 and 15) [140]. In turn, at low pressure (1 bar), the hydrogenation selectivity of $\mathrm{Ni} / \mathrm{C}$ was quite poor (furan: $18 \%$, MF: $30 \%$, MTHF: $14 \%$, and THFA: $30 \%$ ), while Ni-Fe/C will retain its hydrogenation selectivity towards MF with $65 \%$ yield.

For comparison, our research group recently found that $\mathrm{Ni} / \mathrm{C}$ was selective to $\mathrm{MF}$ at $200^{\circ} \mathrm{C}$ with $\mathrm{H}_{2}$ or $260{ }^{\circ} \mathrm{C}$ without $\mathrm{H}_{2}$ in batch conditions; however, in continuous flow regime at $150{ }^{\circ} \mathrm{C}$ under 50 bar $\mathrm{H}_{2}$, the hydrogenation selectivity was quite poor due to side-reaction between furfural and isopropanol. When altering the solvent with non-protic cyclopentyl methyl ether (CPME), two major products, namely FA and THFA, were obtained [141]. These results gave a clear hint that selective hydrogenation could be achieved by changing the reaction regime and conditions. Moreover, in the aforementioned work, two kinds of bimetallic catalysts, $5 \% \mathrm{Ni}-15 \% \mathrm{~W} / \mathrm{C}$ and $10 \% \mathrm{Ni}-15 \% \mathrm{~W} / \mathrm{C}$, were also prepared [142]. Surprisingly, the activities of bimetallic catalysts were relatively lower than that of monometallic catalysts under the same reaction conditions, and poor reaction mass balance was noticed at a higher reaction temperature. Encouragingly, in a continuous flow regime, a better mass balance and a MF yield higher than $70 \%$ was observed with bimetallic catalysts. These promising results suggested that side-reactions could be possibly limited in continuous regime, as the reactant experienced a very short residence time in continuous flow (CF).

In terms of the mechanisms for the reduction of furfural and FA to MF, it was found that hydrogen transfer from i-PrOH to furfural mainly occurs through the formation of a complex between furfural, $\mathrm{i}-\mathrm{PrOH}$, and Lewis acid sites (Scheme 3a), rather than through the production of $\mathrm{H}_{2}$ from isopropanol on the metal surface (Scheme 3b). Koehle and Lobo showed the role of Lewis acid sites of zeolites in the formation of the corresponding hemiacetal (iPrO-MF) by catalytic hydrogen transfer from alcohols to furfural (Meerwein-Ponndorf-Verley or MPV reduction) [143]. In particular, Gilkey et al. [144] have experimentally demonstrated that FA hydrogenolysis via ring activation (Scheme 3c), which will be discussed later, was predominant over direct metal-mediated hydrogenolysis (Scheme 3d), in good agreement with the work that was developed by our research group. 

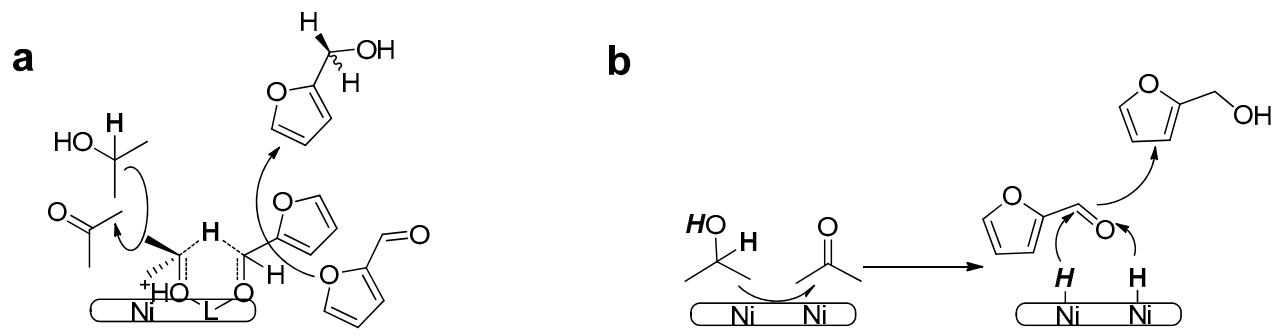

C
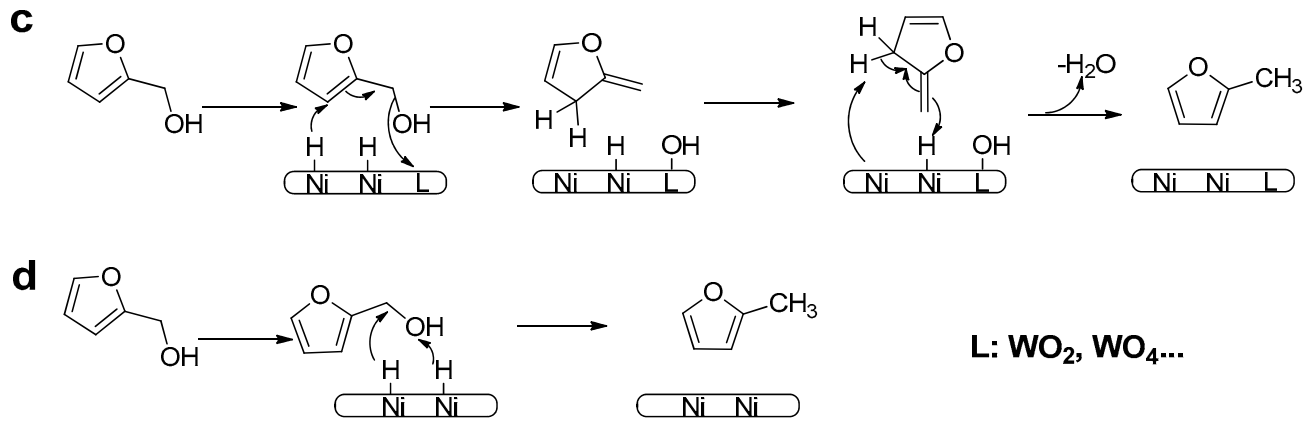

\section{$\mathrm{L}: \mathrm{WO}_{2}, \mathrm{WO}_{4} \cdots$}

Scheme 3. (a) Meerwein-Ponndorf-Verley and (b) metal-mediated furfural hydrogenation; (c) FA hydrogenolysis via ring activation; and, (d) direct FA hydrogenolysis.

Commercial available nickel ferrite nanoparticles catalyst $\left(\mathrm{NiFe}_{2} \mathrm{O}_{4}\right)$ was also exploited as stable and easily separable heterogeneous catalyst for catalytic transfer hydrogenation of furfural to FA,

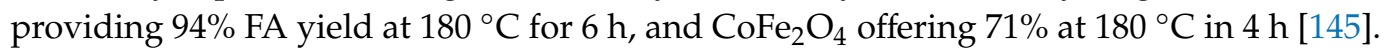

Other metals, such as $\mathrm{Co}, \mathrm{Sn}$, In, etc., were also incorporated with $\mathrm{Ni}$ formed bimetallic catalysts (see Table 2, entries 21-23) [76,146,147]. By supporting Ni and Co on short channeled SBA-15, the catalyst showed superior catalytic performance ( $92 \%$ FA yield) than common SBA- 15 and other acid supports, such as MCM-48, MCF-2, and MCF-41 [146]. On the other hand, bimetallic catalyst $\mathrm{Ni}_{3} \mathrm{Sn}_{2} / \mathrm{Al}_{2} \mathrm{O}_{3}$ did not offer a satisfiable FA yield, even in harsh conditions [147]. Rodiansono et al. developed a method for the preparation of a highly dispersed Ni-Sn alloy catalyst supported on aluminum hydroxide, reaching very good FA selectivity ( $>90 \%)$ [148]. Later on, the authors prepared analogous Ni-In and $\mathrm{Ni}-\mathrm{Zr}$ bimetallic catalysts. Both of the materials showed similar catalytic performance, although it is worth mentioning that, for $\mathrm{Ni}-\mathrm{Zr} / \mathrm{AlOH}$, a further hydrogenation compound, namely THFA, was obtained as the major product (Table 2, entries 23 and 26) [76].

In general, Co-based catalysts showed good hydrogenation selectivity to FA, despite great differences in supports, $\mathrm{H}$ resources, solvent types, and reaction conditions. However, the catalytic activity over Ni-based catalysts varied from all of these parameters. For instance, Table 2, entries 10-12 indicated furfural hydrogenation selectivity over $\mathrm{Ni} / \mathrm{AC}-\mathrm{SO}_{3} \mathrm{H}$ is highly dependent on reaction temperature and $\mathrm{H}$ resources; the introduction of $\mathrm{Zr}$ instead of $\mathrm{Sn}$ into $\mathrm{Ni} / \mathrm{AlOH}$ dramatically changed the desired compound from THFA to FA, and our previous study also proved that the reaction regimes could affect furfural hydrogenation selectivity. 
Table 2. Furfural hydrogenation over Co, Ni-based catalysts.

\begin{tabular}{|c|c|c|c|c|c|c|c|c|c|c|c|}
\hline \multirow{2}{*}{ Entry } & \multirow{2}{*}{ Catalyst } & \multirow{2}{*}{ H Source } & \multirow{2}{*}{ Solvent } & \multirow{2}{*}{ Temperature $\left({ }^{\circ} \mathrm{C}\right)$} & \multirow{2}{*}{ Time (h) } & \multirow{2}{*}{ Pressure (bar) } & \multicolumn{4}{|c|}{ Yield (\%) } & \multirow{2}{*}{ Ref. } \\
\hline & & & & & & & FA & MF & THFA & MTHF & \\
\hline 1 & Co/SBA-15 & $\mathrm{H}_{2}$ & $\mathrm{EtOH}$ & 150 & 1.5 & 20 & 88 & - & - & - & {$[137]$} \\
\hline 2 & $\mathrm{Co} / \mathrm{TiO}_{2}$ & $\mathrm{H}_{2}$ & - & 80 & $17.5^{a}$ & 23.4 & 95 & - & - & - & [138] \\
\hline 3 & $\mathrm{Co} / \mathrm{CPNs}$ & $\mathrm{H}_{2}$ & i-PrOH & 180 & 2.5 & 30 & 98 & - & - & - & [82] \\
\hline 4 & $\mathrm{Co} / \mathrm{NCNTS}$ & $\mathrm{H}_{2}$ & $\mathrm{H}_{2} \mathrm{O}$ & 110 & 5 & 40 & 92 & - & - & - & [73] \\
\hline 5 & $\mathrm{Ni} / \mathrm{NCNTs}$ & $\mathrm{H}_{2}$ & $\mathrm{H}_{2} \mathrm{O}$ & 100 & 7 & 40 & 0 & - & 100 & - & [73] \\
\hline 6 & $\mathrm{Ni} / \mathrm{C}$ & $\mathrm{H}_{2}$ & - & 120 & 2 & 10 & - & - & 100 & - & [70] \\
\hline 7 & $\mathrm{Ni} / \mathrm{Ba}-\mathrm{Al}_{2} \mathrm{O}_{3}$ & $\mathrm{H}_{2}$ & - & 140 & 4 & 40 & - & - & 96 & - & [71] \\
\hline 8 & $\mathrm{Ni} / \mathrm{CN}$ & $\mathrm{H}_{2}$ & i-PrOH & 200 & 4 & 10 & 91 & 2 & 2 & 1 & [74] \\
\hline 9 & Capped Ni NPs & $\mathrm{H}_{2}$ & i-PrOH & 110 & 3 & 30 & 96 & - & 4 & - & [77] \\
\hline 10 & $\mathrm{Ni} / \mathrm{AC}-\mathrm{SO}_{3} \mathrm{H}$ & $\mathrm{H}_{2}$ & $\mathrm{i}-\mathrm{PrOH}$ & 60 & 8 & 40 & 100 & - & - & - & [80] \\
\hline 11 & $\mathrm{Ni} / \mathrm{AC}-\mathrm{SO}_{3} \mathrm{H}$ & $\mathrm{H}_{2}$ & i-PrOH & 100 & 5 & 40 & - & - & 100 & - & [80] \\
\hline 12 & $\mathrm{Ni} / \mathrm{AC}-\mathrm{SO}_{3} \mathrm{H}$ & $\mathrm{i}-\mathrm{PrOH}$ & $\mathrm{i}-\mathrm{PrOH}$ & 140 & 4 & $40^{b}$ & 100 & - & - & - & [80] \\
\hline 13 & $\mathrm{Ni}_{2} / \mathrm{MgAl}$ & $\mathrm{H}_{2}$ & - & 180 & $1.8^{a}$ & 1 & 92 & - & 4 & - & [77] \\
\hline 14 & $\mathrm{NiCl}$ & $\mathrm{H}_{2}$ & - & 180 & $4^{a}$ & 33 & 1 & 1 & 5 & 56 & [140] \\
\hline 15 & $\mathrm{NiFe} / \mathrm{C}$ & $\mathrm{H}_{2}$ & - & 180 & $4^{a}$ & 33 & 4 & 72 & 2 & 6 & [140] \\
\hline 16 & $\mathrm{Ni} / \mathrm{C}$ & $\mathrm{H}_{2}$ & i-PrOH & 200 & 5 & 30 & 6 & 66 & 1 & 2 & [141] \\
\hline 17 & $\mathrm{Ni} / \mathrm{C}$ & $\mathrm{i}-\mathrm{PrOH}$ & $\mathrm{i}-\mathrm{PrOH}$ & 260 & 5 & 1 & 20 & 50 & 1 & 1 & [141] \\
\hline 18 & $\mathrm{Ni} / \mathrm{C}$ & $\mathrm{H}_{2}$ & CPME & 150 & nd & 50 & 39 & 2 & 32 & 0 & [141] \\
\hline 19 & No-W/C & $\mathrm{i}-\mathrm{PrOH}$ & $\mathrm{i}-\mathrm{PrOH}$ & 230 & 1 & 30 & 0 & 70 & 0 & 0 & [142] \\
\hline 20 & $\mathrm{NiFe}_{2} \mathrm{O}_{4}$ & $\mathrm{i}-\mathrm{PrOH}$ & $\mathrm{i}-\mathrm{PrOH}$ & 180 & 6 & - & 94 & - & - & - & [145] \\
\hline 21 & $\mathrm{Ni}-\mathrm{Co} / \mathrm{SBA}-15$ & $\mathrm{H}_{2}$ & $\mathrm{EtOH}$ & 90 & 2 & 50 & 92 & - & - & - & [146] \\
\hline 22 & $\mathrm{Ni}_{3} \mathrm{Sn}_{2} / \mathrm{Al}_{2} \mathrm{O}_{3}$ & $\mathrm{H}_{2}$ & - & 280 & $0.5^{a}$ & 1 & 41 & - & - & - & [147] \\
\hline 23 & $\mathrm{Ni}-\mathrm{In} / \mathrm{AlOH}$ & $\mathrm{H}_{2}$ & i-PrOH & 180 & 3 & 30 & 92 & - & 4 & - & [76] \\
\hline 24 & Raney Ni/AlOH & $\mathrm{H}_{2}$ & $\mathrm{i}-\mathrm{PrOH}$ & 180 & 1.25 & 30 & 1 & - & 99 & - & [76] \\
\hline 25 & $\mathrm{Ni}-\mathrm{Sn} / \mathrm{AlOH}$ & $\mathrm{H}_{2}$ & $\mathrm{i}-\mathrm{PrOH}$ & 180 & 1.25 & 30 & 91 & - & 3 & - & [76] \\
\hline 26 & $\mathrm{Ni}-\mathrm{Zr} / \mathrm{AlOH}$ & $\mathrm{H}_{2}$ & $\mathrm{i}-\mathrm{PrOH}$ & 180 & 1.25 & 30 & 0 & - & 96 & - & [76] \\
\hline
\end{tabular}

${ }^{a}$ LHSV in $\mathrm{h}^{-1},{ }^{b} \mathrm{~N}_{2}$. 


\subsection{Zr-Based and Other Catalysts}

$\mathrm{Zr}$-based compounds have proved to be efficient catalysts for furfural hydrogenation, especially by the Meerwein-Ponndorf-Verley (MPV) reduction. Recently, $\mathrm{ZrO}_{2}$ that was prepared by the microemulsion method showed excellent transfer hydrogenation selectivity to FA ( $\geq 98 \%)$, although FA yield only rose up to $53 \%$ in $120 \mathrm{~h}$, most likely due to relative lower reaction temperature $\left(100{ }^{\circ} \mathrm{C}\right)$ employed for the reaction. In addition, the effect of microwave irradiation was clearly evidenced, accelerating the reaction 15-30 times in comparison with conventional heating method [149]. $\mathrm{Zr}(\mathrm{OH})_{4}$ (might actually existed in the form of $\mathrm{ZrO}(\mathrm{OH})_{2} \cdot \mathrm{xH}_{2} \mathrm{O}$ ) also showed almost stoichiometric FA yield when using iso-propanol as hydrogen source and solvent (Table 3, entry 2) [150]. The experimental results indicated that basic centers in $\mathrm{Zr}(\mathrm{OH})_{4}$ displayed a pronounced improvement of furfural transfer hydrogenation, while moderate monoclinic phase content in $\mathrm{ZrO}_{2-x}$ could enhance the conversion rate and FA selectivity. Scheme 4 illustrated the proposed mechanism for the transformation of furfural into FA catalyzed by $\mathrm{Zr}(\mathrm{OH})_{4}$ via catalytic transfer hydrogenation with iso-propanol. In detail, iso-propanol was firstly adsorbed on the catalyst surface formed alkoxide, and furfural was then absorbed on the surface forming a six-membered ring transition state with the above-mentioned alkoxide (like the case in Scheme 3a), then hydrogen transfer occurred and released one mole acetone. Finally, another iso-propanol molecule formed the corresponding alkoxide, like in the first step, and give a hydrogen atom to the oxygen atom of furfural generating the final product FA.

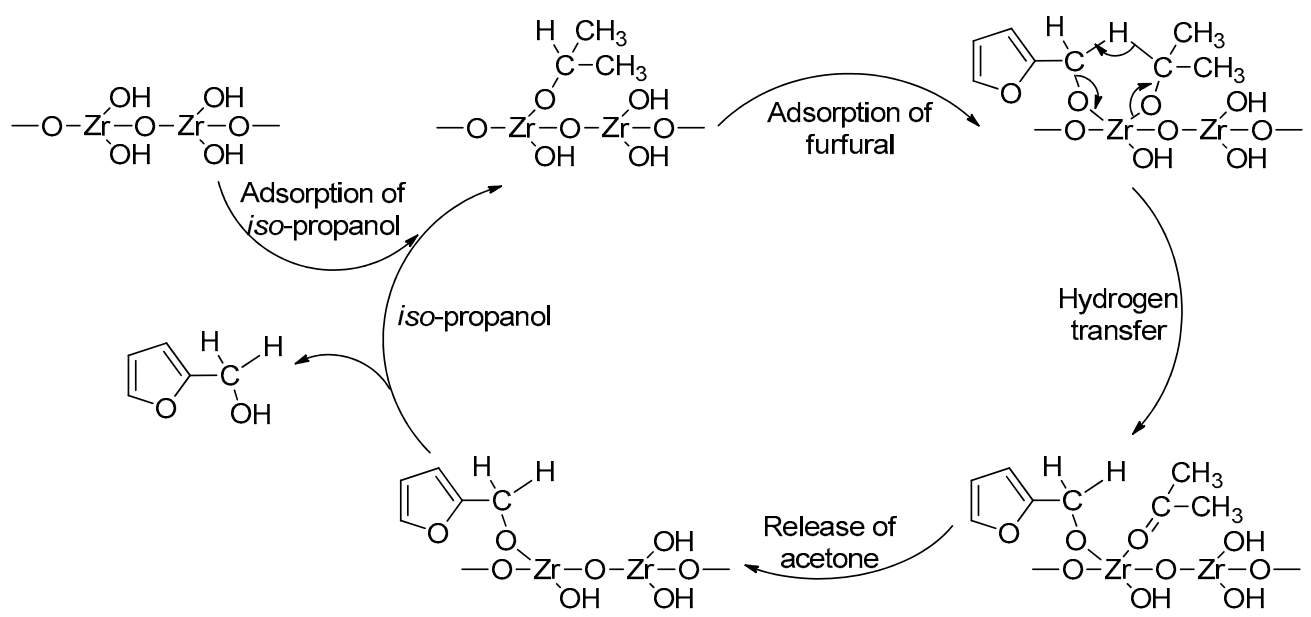

Scheme 4. Proposed mechanism for the transformation of furfural into FA catalyzed by $\mathrm{Zr}(\mathrm{OH})_{4}$ via catalytic transfer hydrogenation with iso-propanol as a hydrogen donor. Adapted from Zhang et al. [150].

Sha et al. developed a super-efficient catalyst $\mathrm{Zr}$-HAs by combining $\mathrm{Zr}$ with humic acid. A FA yield of $97 \%$ was obtained via MPV reduction at very mild conditions (Table 3, entry 3) [151]. Furthermore, $\mathrm{Li}$ et al. synthesized recyclable Hf-phenylphosphonate nanohybrids (PhP-Hf) via the assembly of phenylphosphonate with $\mathrm{HfCl}_{4}$. 98\% FA yield, with a formation rate of $9760 \mu \mathrm{mol} / \mathrm{g} / \mathrm{h}$ was obtained at $120{ }^{\circ} \mathrm{C}$ for $2 \mathrm{~h}$, being, the superior catalytic activity of PhP-Hf, mainly attributed to its moderate acidity and relatively strong basicity [152]. Simultaneously, $\mathrm{PhP}-\mathrm{Zr}$ showed lower activity than PhP-Hf (Table 3, entries 4 and 5), which is in good agreement with the catalytic activity order that was obtained by theoretical studies: $\mathrm{Hf}>\mathrm{Zr}>\mathrm{Sn}[143,153]$.

It is noteworthy to mention that alumina-carbon composite catalyst $\left(\mathrm{Al}_{2} \mathrm{O}_{3}-\mathrm{S}\right)$, synthesized by reaction between $\mathrm{Al}\left(\mathrm{NO}_{3}\right)_{3}$. with the polyether-based surfactant, showed a comparable FA yield $(96 \%)$ with Zr-based catalysts though catalytic transfer hydrogenation. The high selectivity observed was attributed to the presence of acid sites on the catalyst [154]. Nonetheless, the gradual deactivation of the catalyst was observed due to $\mathrm{Al}$ species leaching.

Recently, Wu et al. presented a rapid and mild-conditions approach for the quantitative production of FA in presence of KF and a liquid H-donnor: polymethylhydrosiloxane (PMHS). It was reported a 
$97 \% \mathrm{FA}$ yield in $30 \mathrm{~min}$. of reaction, at room temperature. To the best of our knowledge, this contribution presents the production of FA at the mildest conditions. Although supported Ir on hydrogenated $\mathrm{MoO}_{x}$ catalyst could rise a $99 \% \mathrm{FA}$ at $30^{\circ} \mathrm{C}$, the reaction time was $6 \mathrm{~h}$ and the experiments were performed under 20 bar of $\mathrm{H}_{2}$ pressure (Table 3, entry 8) [155]. In the presence of $\mathrm{H}_{2}, \mathrm{Fe} / \mathrm{C}$ combined with $\mathrm{K}_{2} \mathrm{CO}_{3}$ achieved $94 \%$ of $\mathrm{FA}$ yield under harsh conditions $\left(220^{\circ} \mathrm{C}\right)$. Interestingly, when the reaction was performed in the presence of $\mathrm{O}_{2}$, furfural was selectively converted to furan-2-acroleinin [156].

In terms of furfural deep hydrogenation, Lee et al. investigated the hydrodeoxygenation of furfural to MF on molybdenum carbide catalyst [157]. The best MF selectivity was around $56 \%$, and the conversion of furfural was less than $10 \%$, which could be possibly associated with the relatively lower reaction temperature $\left(150^{\circ} \mathrm{C}\right)$. Grazia et al. found out that the $\mathrm{MgO}$ and $\mathrm{Mg} / \mathrm{Fe} / \mathrm{O}$ catalysts were active for furfural transfer hydrogenation reaction, and $\mathrm{MgO}$ was selective for FA formation, whereas $\mathrm{Mg} / \mathrm{Fe} / \mathrm{O}$ showed to be highly active and selective for MF production (Table 3, entries 10 and 11). Further studies, using $\mathrm{FeVO}_{4}$ as catalyst, reported a similar MF yield of $80 \%$ under the same system [158].

Table 3. Furfural hydrogenation over Zr-based and other catalysts.

\begin{tabular}{|c|c|c|c|c|c|c|c|c|c|c|c|}
\hline \multirow{2}{*}{ Entry } & \multirow{2}{*}{ Catalyst } & \multirow{2}{*}{$\begin{array}{c}\mathbf{H} \\
\text { Source }\end{array}$} & \multirow{2}{*}{ Solvent } & \multirow{2}{*}{$\begin{array}{c}\text { Temperature } \\
\left({ }^{\circ} \mathrm{C}\right)\end{array}$} & \multirow{2}{*}{$\begin{array}{l}\text { Time } \\
\text { (h) }\end{array}$} & \multirow{2}{*}{$\begin{array}{l}\text { Pressure } \\
\text { (bar) }\end{array}$} & \multicolumn{4}{|c|}{ Yield (\%) } & \multirow{2}{*}{ Ref. } \\
\hline & & & & & & & FA & MF & THFA & MTHF & \\
\hline 1 & $\mathrm{ZrO}_{2}$ & i-PrOH & $\mathrm{i}-\mathrm{PrOH}$ & 100 & 120 & - & 53 & - & - & - & [149] \\
\hline 2 & $\mathrm{Zr}(\mathrm{OH})_{4}$ & i-PrOH & $\mathrm{i}-\mathrm{PrOH}$ & 170 & 2.5 & 10 & 99 & - & - & - & [150] \\
\hline 3 & ZrHAs & i-PrOH & $\mathrm{i}-\mathrm{PrOH}$ & 50 & 15 & - & 97 & - & - & - & [151] \\
\hline 4 & $\mathrm{PhP}-\mathrm{Zr}$ & i-PrOH & $\mathrm{i}-\mathrm{PrOH}$ & 120 & 2 & - & 78 & - & - & - & [152] \\
\hline 5 & PhP-Hf & i-PrOH & i-PrOH & 120 & 2 & - & 98 & - & - & - & [152] \\
\hline 6 & $\mathrm{Al}_{2} \mathrm{O}_{3}-\mathrm{S}$ & i-PrOH & $\mathrm{i}-\mathrm{PrOH}$ & 130 & 6 & - & 96 & - & - & - & [154] \\
\hline 7 & $\mathrm{KF}$ & PMHS & DMF & 25 & 0.5 & - & 97 & - & - & - & [159] \\
\hline 8 & $\mathrm{Ir} / \mathrm{H}$ doping $\mathrm{MoOx}$ & $\mathrm{H}_{2}$ & $\mathrm{H}_{2} \mathrm{O}$ & 30 & 6 & 20 & 99 & - & - & - & [155] \\
\hline 9 & $\mathrm{Fe} / \mathrm{C}+\mathrm{K}_{2} \mathrm{CO}_{3}$ & $\mathrm{H}_{2}$ & $\mathrm{EtOH}$ & 220 & 2 & 20 & 93 & - & 3 & - & [156] \\
\hline 10 & $\mathrm{MgO}$ & $\mathrm{MeOH}$ & $\mathrm{MeOH}$ & 250 & 1 & 1 & 58 & - & - & - & [160] \\
\hline 11 & $\mathrm{Mg} / \mathrm{Fe} / \mathrm{O}$ & $\mathrm{MeOH}$ & $\mathrm{MeOH}$ & 380 & 1 & 1 & - & 83 & - & - & [160] \\
\hline 12 & $\mathrm{FeVO}_{4}$ & $\mathrm{MeOH}$ & $\mathrm{MeOH}$ & 320 & $3^{a}$ & 1 & - & 80 & - & - & [158] \\
\hline
\end{tabular}

${ }^{a}$ TOS in h.

Generally, the Zr-based catalysts were used as for furfural transfer hydrogenation, and high selectivity was observed for FA production. The nature of acidic and basic sites of this kind of catalysts played a key role for their activity. For other catalysts (e.g., $\mathrm{Mg} / \mathrm{Fe} / \mathrm{O}$ and $\mathrm{FeVO}_{4}$ ), relatively harsh reaction temperature should be attributed to furfural hydrogenation selectivity to MF.

\section{Noble Metal Catalysts}

Noble metals, which were regarded as potential catalysts for hydrogenation, have been extensively studied with promising prospect. When compared with non-noble metal, noble metal catalysts generally gave rise to higher reaction activity and efficiency under a relatively milder condition, especially for the production of deep hydrogenation products, such as MF and THFA, etc. Unlike non-noble metal, studies on noble metal-based materials must be specially directed to the optimization of their performances and recyclability due to their low production in nature.

\subsection{Pd Based Catalysts}

Taking Pd based catalysts as an example, various Pd supported catalysts were tested for furfural hydrogenation in continuous flow $[83,92,161]$. Continuous processing has been as well contrasted with batch production. In this regard, continuous flow processing has a number of significant and inherent advantages for biomass processing when compared to batch reactor technologies:

$\checkmark$ Continuous flow processing allows a better control of reaction conditions.

$\checkmark$ Flow processing also facilitates scaling up which is an important point taking into consideration that many of the biomass valorization processes are still in the lab scale. 
$\checkmark$ The utilization of flow processing approaches allow the intensification of the chemical processes, thereby significantly contributing to simplify technologies.

$\checkmark \quad$ Unlike batch processing, fixed-bed flow technologies do not require catalyst separation after reaction and regeneration, if required. It is readily performed over the same catalytic bed.

$\checkmark$ Safety is increased, as flow operation allows for the continuous removal of gases, which might not interfere in the main catalytic process. However, gases that were generated in batch reactors could lead to increase pressure and potentially result in new and uncontrolled processes.

$\checkmark$ Multi step reactions can be arranged in a continuous sequence. This can be especially beneficial if intermediate compounds are unstable, toxic, or sensitive to air, since they will only exist momentarily and in small quantities.

The group of Luque has made a great contribution on flow chemistry concerning biomass valorization. For instance, $76 \%$ of $\mathrm{MF}$ was attained at very mild temperature $\left(90^{\circ} \mathrm{C}\right)$ with $\mathrm{Pd} / \mathrm{C}$ in continuous flow regime (Table 4, entries 1-3). Interestingly, at a higher temperature $\left(150{ }^{\circ} \mathrm{C}\right)$, the reaction selectivity changed to THFA. The opposite result was obtained with Pd/MAGSNC, which produced THFA when the reaction was performed at $90{ }^{\circ} \mathrm{C}$ and FA at $150{ }^{\circ} \mathrm{C}$ (Table 4 , entries 4 and 5). Herein, it should be noted that selective hydrogenation of furfural could be achieved not only by changing the temperature, but also by varying the flow rate that determines the residence time of reactant in the catalytic system. In these cases, it seems that furfural catalytic valorization over Pd based catalysts led to the formation of FA and THFA. From a mechanistic point of view, these results could be possibly explained, since the most stable adsorption conformation of furfural was with the furan ring lying flat on the $\mathrm{Pt}$ (111) surface [162], favoring its hydrogenation. Indeed, catalytic systems that are based on Pd nanoparticles supported on different materials, such as carbon, bio-char, $\mathrm{TiO}_{2}$, and $\mathrm{Al}_{2} \mathrm{O}_{3}$, among others, would result in different yields of FA and THFA [87,91,163-166]. Some of them exhibited excellent catalytic performance, for example, Pd supported on hydroxyapatite (HAP) and MIL-101(Cr)- $\mathrm{NH}_{2}$ gave rise to $100 \%$ THFA yield $[88,89]$. Noticeable difference could be found with $\mathrm{Pd} / \mathrm{Al}_{2} \mathrm{O}_{3}$ as catalyst (see Table 4, entries 13-15).

THFA yield severely decreased by using water rather than iso-propanol as solvent with lower $\mathrm{H}_{2}$ pressure. Interestingly, the side-product was identified as tetrahydrofurfural with $84 \%$ yield, which could be understood considering that the catalytic reaction occurred on a double bond of the furan ring rather than in the aldehyde group, under the reaction conditions [33]. Hu et al. suggested that polar solvents facilitate efficient furfural hydrogenation and tended to favor the hydrogenation of the furan ring over that of the carbonyl group [163]. They obtained $6 \%$ of tetrahydrofurfural with non-polar diethyl ether as solvent by performing the experiment with $\mathrm{Pd} / \mathrm{C}$ at $170{ }^{\circ} \mathrm{C}$ under $70 \mathrm{bar}$ total pressure $\left(\mathrm{H}_{2}\right.$ pressure $>40$ bar). Apart from the effect of the support, solvent, reaction conditions, and different metal reduction methods for the catalysts preparation, also showed significant influence on the catalytic performance. For instance, Pd catalysts that were prepared via chemical reduction method exhibited smaller particle sizes and higher metal dispersions, leading to greater conversions than those that were achieved using catalysts prepared via impregnation followed by the thermal reduction method [90]. Date et al. systematically investigated the effect of different particle size of $\mathrm{Pd} / \mathrm{C}$ catalysts on furfural hydrogenation [167]. Authors found out that, by using $\mathrm{NaBH}_{4}$ as the reduction agent, the smallest crystallite size $(4.8 \mathrm{~nm})$ was obtained, mainly attributed to the incorporation of $B$ into the inner lattices of Pd-Pd. In turn, the use of formaldehyde as reduction agent gave rise to the highest size $(22.4 \mathrm{~nm})$. The systematic study of crystallite size and products selectivity revealed that smaller crystallite size enhanced the selectivity of MTHF and THF, which that means ring hydrogenation and decarbonylation reaction were promoted with smaller Pd particle size. This result is in line with the study of Bhogeswararao and Srinivas, who noticed that THFA yield increased and FA yield decreased with Pd particle size decreased from $7.8 \mathrm{~nm}$ to $5.8 \mathrm{~nm}$, and furfural conversion decreased at the same time [165]. It seems that the Pd particle size has a negative effect on catalysts activity (in terms of furfural conversion/mol $\mathrm{md}_{\mathrm{Pd}}$ [ $[91,165]$. Figure 5 shows the catalytic results of Pd based catalysts with different supports. 


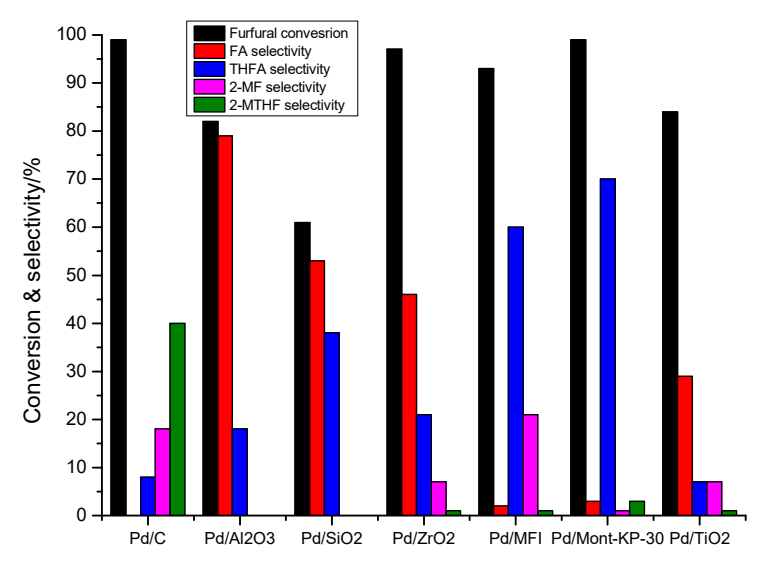

Figure 5. Pd based catalyst screening for hydrogenation of furfural with different supports. Adapted from Date et al. [167]. Reaction conditions: Furfural, $5 \mathrm{~g}$; Solvent, Isopropyl alcohol (95 g); Temperature, $220^{\circ} \mathrm{C}$; Pressure, 500 psi; Agitation Speed, 1000 rpm, Catalyst, $4 \%$ metal loading; loading, 0.5 g; Reaction time, $5 \mathrm{~h}$.

Bimetallic catalysts containing Pd supported on different materials have been recently reported. The selectivity varied within different metals and supports, for example, $\mathrm{Pd}-\mathrm{Ni} / \mathrm{MWNT}$ gave rise to $83 \%$ yield of THFA, $\mathrm{Pd}-\mathrm{Fe} / \mathrm{SiO}_{2}$ offered $83 \%$ of MF yield, $\mathrm{Pd}-\mathrm{Fe} / \mathrm{Al}_{2} \mathrm{O}_{3}$ resulted in $43 \%$ of furan, while $\mathrm{Pd}-\mathrm{Cu} / \mathrm{TiO}_{2}$ and $\mathrm{Pd}-\mathrm{Pt} / \mathrm{TiO}_{2}$ attained $98 \%$ of FA and $95 \%$ THFA yield, respectively (Table 4 , entries 24-27). Consistent with non-noble metal catalysts, without rigorous high temperature, the major product will be FA with a Pd based catalyst via transfer hydrogenation. Herein, it is worth pointing out that the transfer hydrogenation could be performed at $25^{\circ} \mathrm{C}$ with $\mathrm{NaH}_{2} \mathrm{PO}_{2}$ as $\mathrm{H}$-donor, in spite of relatively poor FA yield (68\%) [93].

In terms of Pd-based catalysts, furfural hydrogenation activity and selectivity relied on the supports, Pd nanoparticle size, temperature, reaction regime, and solvent type, etc. Acidic supports favor furfural conversion, and a smaller Pd particle size led to deep the hydrogenation of FA to THFA. Moreover, continuous flow showed encouraging improvement on catalyst activity and hydrogenation products productivity. Bimetallic Pd-based catalysts not only improved furfural hydrogenation activity, but also changed reaction selectivity.

\subsection{Pt Based Catalysts}

The hydrogenation of furfural with Pt based catalysts differs with the results that were obtained for Pd-modified materials, since, in most of cases, FA and MF or furan were formed rather than THFA. Therefore, it can be understood that, by employing Pt based catalyst, the reaction preferably occurs on the aldehyde group via hydrogenation, hydrodeoxygenation, or decarboxylation. Furthermore, Taylor et al. suggested that the hydrogenation of furfural on $\mathrm{Pt}$ (111) depends on the used conditions (Figure 6) [172], since furfural adopts a planar motif at low coverage and a more tilted geometry at higher coverage. The difference of furfural adsorption configurations on the catalyst obviously plays an important role on the hydrogenation selectivity. Even different supports and second metal introduction in Pt-based catalysts also showed a remarkable effect on furfural conversion and products selectivity, no apparent changes were found with Pt nanoparticle size ranged from $1.6 \mathrm{~nm}$ to $36.1 \mathrm{~nm}[97,140,165,173-175]$, which means that the particle size of Pt has little effect on furfural hydrogenation selectivity. 
Table 4. Furfural hydrogenation over Pd-based catalysts.

\begin{tabular}{|c|c|c|c|c|c|c|c|c|c|c|c|}
\hline \multirow{2}{*}{ Entry } & \multirow{2}{*}{ Catalyst } & \multirow{2}{*}{ H Source } & \multirow{2}{*}{ Solvent } & \multirow{2}{*}{ Temperature $\left({ }^{\circ} \mathrm{C}\right)$} & \multirow{2}{*}{ Time (h) } & \multirow{2}{*}{ Pressure (bar) } & \multicolumn{4}{|c|}{ Yield (\%) } & \multirow{2}{*}{ Ref. } \\
\hline & & & & & & & FA & MF & THFA & MTHF & \\
\hline 1 & $\mathrm{Pd} / \mathrm{C}$ & $\mathrm{H}_{2}$ & EtAc & 90 & $20^{a}$ & 50 & 0 & 76 & - & - & {$[83]$} \\
\hline 2 & Pd/PBSAC & $\mathrm{H}_{2}$ & EtAc & 90 & $20^{a}$ & 50 & 72 & 8 & - & - & [83] \\
\hline 3 & Pd/AlSBAred & $\mathrm{H}_{2}$ & EtAc & 90 & $20^{a}$ & 50 & - & - & 91 & - & [161] \\
\hline 4 & $\mathrm{Pd} / \mathrm{MAGSNC}$ & $\mathrm{H}_{2}$ & EtAc & 150 & $20^{a}$ & 50 & 74 & - & 26 & - & [92] \\
\hline 5 & Pd/MAGSNC & $\mathrm{H}_{2}$ & EtAc & 90 & $20^{a}$ & 50 & 17 & - & 83 & - & [92] \\
\hline 6 & $\mathrm{Pd} / \mathrm{SBA}-15$ & $\mathrm{H}_{2}$ & EtAc & 150 & $20^{a}$ & 50 & 8 & - & 77 & - & [92] \\
\hline 7 & Pd/SBA-15 & $\mathrm{H}_{2}$ & EtAc & 150 & $150^{a}$ & 50 & 22 & - & 58 & - & [92] \\
\hline 8 & $\mathrm{Pd} / \mathrm{C}$ & $\mathrm{H}_{2}$ & EtAc & 150 & $20^{a}$ & 50 & 0 & - & 74 & - & [92] \\
\hline 9 & $\mathrm{Pd} / \mathrm{C}$ & $\mathrm{H}_{2}$ & EtAc & 150 & $150^{a}$ & 50 & 0 & - & 80 & - & [92] \\
\hline 10 & $\mathrm{Pd} / \mathrm{BCH}$ & $\mathrm{H}_{2}$ & - & 110 & 265 & 4 & 65 & - & 15 & - & [164] \\
\hline 11 & $\mathrm{Pd} / \mathrm{TiO}_{2}$ & $\mathrm{H}_{2}$ & i-PrOH & 30 & 240 & 3 & - & - & 42 & - & [91] \\
\hline 12 & $\mathrm{Pd}-\mathrm{Pt} / \mathrm{TiO}_{2}$ & $\mathrm{H}_{2}$ & $\mathrm{i}-\mathrm{PrOH}$ & 30 & 240 & 3 & - & - & 95 & - & [91] \\
\hline 13 & $\mathrm{Pd} / \mathrm{Al}_{2} \mathrm{O}_{3}$ & $\mathrm{H}_{2}$ & $\mathrm{i}-\mathrm{PrOH}$ & 25 & 480 & 60 & - & - & 79 & - & [165] \\
\hline 14 & $\mathrm{Pd} / \mathrm{Al}_{2} \mathrm{O}_{3}$ & $\mathrm{H}_{2}$ & $\mathrm{H}_{2} \mathrm{O}$ & 30 & 240 & 5 & 0 & - & 16 & - & [33] \\
\hline 15 & $\mathrm{Pd} / \mathrm{Al}_{2} \mathrm{O}_{3}$ & $\mathrm{H}_{2}$ & $\mathrm{H}_{2} \mathrm{O}$ & 90 & 120 & 20 & 28 & - & 72 & - & [166] \\
\hline 16 & $\mathrm{Pd} / \mathrm{HAP}$ & $\mathrm{H}_{2}$ & $\mathrm{i}-\mathrm{PrOH}$ & 40 & 180 & 10 & - & - & 100 & - & [89] \\
\hline 17 & $\mathrm{Pd} / \mathrm{C}$ & $\mathrm{H}_{2}$ & $\mathrm{H}_{2} \mathrm{O}-\mathrm{CO}_{2}$ & 40 & 30 & 30 & 62 & - & 9 & - & [87] \\
\hline 18 & Pd/MIL-101 (Cr)-NH2 & $\mathrm{H}_{2}$ & $\mathrm{H}_{2} \mathrm{O}$ & 40 & 240 & 20 & - & - & 100 & - & {$[88]$} \\
\hline 19 & $\mathrm{Pd} / \mathrm{CB}$ & $\mathrm{H}_{2}$ & $\mathrm{H}_{2} \mathrm{O}$ & 50 & 30 & 5 & 29 & - & - & - & {$[84]$} \\
\hline 20 & $\mathrm{Pd} / \mathrm{CNT}$ & $\mathrm{H}_{2}$ & $\mathrm{H}_{2} \mathrm{O}$ & 50 & 30 & 20 & 39 & - & - & - & [84] \\
\hline 21 & $\mathrm{Pd} / \mathrm{C}$ & $\mathrm{H}_{2}$ & EtOEt & 170 & 60 & $70^{b}$ & - & - & 69 & - & [163] \\
\hline 22 & $\mathrm{Pd} / \mathrm{C}^{c}$ & $\mathrm{H}_{2}$ & $\mathrm{i}-\mathrm{PrOH}$ & 180 & 300 & 20 & - & 44 & 34 & - & {$[90]$} \\
\hline 23 & $\mathrm{Pd} / \mathrm{C}^{d}$ & $\mathrm{H}_{2}$ & $\mathrm{i}-\mathrm{PrOH}$ & 180 & 300 & 20 & - & 18 & 57 & - & [90] \\
\hline 24 & $\mathrm{Pd}-\mathrm{Fe} / \mathrm{SiO}_{2}$ & $\mathrm{H}_{2}$ & $\mathrm{i}-\mathrm{PrOH}$ & 250 & $4.5^{e}$ & 1 & - & 83 & 6 & - & [168] \\
\hline 25 & $\mathrm{Pd}-\mathrm{Fe} / \mathrm{Al}_{2} \mathrm{O}_{3}$ & $\mathrm{H}_{2}$ & $\mathrm{i}-\mathrm{PrOH}$ & 250 & $4.5^{e}$ & 1 & 20 & 5 & 4 & - & [168] \\
\hline 26 & Pd-Ni/MWNT & $\mathrm{H}_{2}$ & $\mathrm{EtOH}$ & 130 & 300 & 30 & - & - & 83 & - & [94] \\
\hline 27 & $\mathrm{Pd}-\mathrm{Cu} / \mathrm{TiO}_{2}$ & $\mathrm{H}_{2}$ & $\mathrm{H}_{2} \mathrm{O}$ & 110 & 80 & 6 & 98 & - & - & - & [169] \\
\hline 28 & $\mathrm{Pd}-\mathrm{Cu} / \mathrm{C}$ & $\mathrm{HCOOH}$ & 1,4-dioxane & 170 & 180 & - & 99 & - & - & - & [170] \\
\hline 29 & $\mathrm{Pd} / \mathrm{NPC}$ & 2-BuOH & 2-BuOH & 120 & 600 & - & 90 & - & - & - & [171] \\
\hline 30 & $\mathrm{Pd} / \mathrm{Al}_{2} \mathrm{O}_{3}$ & $\mathrm{NaH}_{2} \mathrm{PO}_{2}$ & THF- $\mathrm{H}_{2} \mathrm{O}$ & 25 & 60 & - & 68 & - & - & - & [93] \\
\hline
\end{tabular}

${ }^{a}$ TOS in min. ${ }^{b}$ total pressure. ${ }^{c}$ thermal reduction. ${ }^{d}$ chemical reduction. ${ }^{e} \mathrm{~W} / \mathrm{F}=$ catalyst mass/mass flow rate of reactant reduction. 


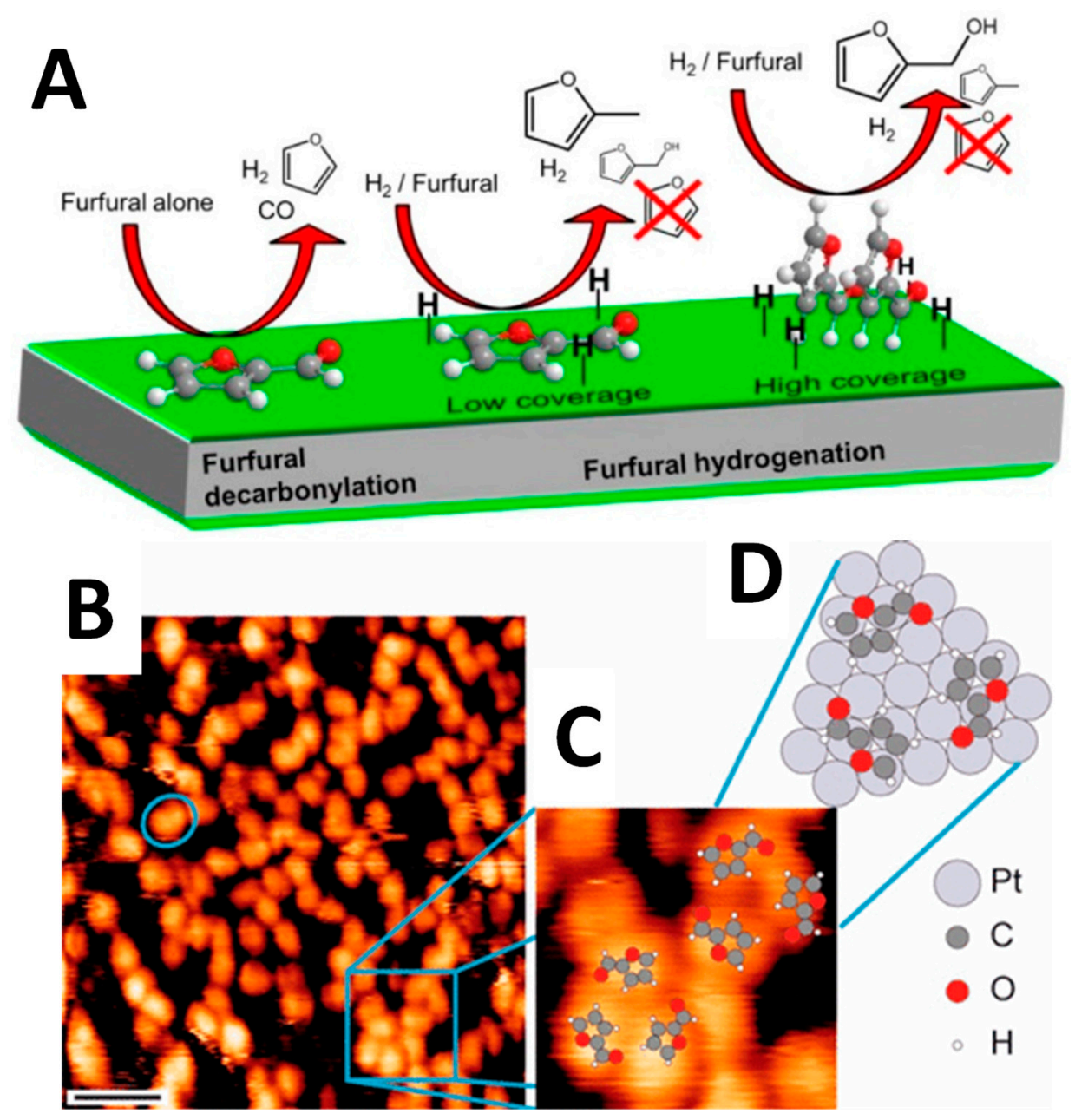

Figure 6. (A) Catalytic hydrogenation and hydrodeoxygenation of furfural over Pt(111); (B) STM image with a single furfural molecule indicated by the blue circle $(\mathrm{T}=145 \mathrm{~K}, \mathrm{Vt}=1.28 \mathrm{~V}, \mathrm{It}=0.12$ $\mathrm{nA}$ ). Thescale bar (black line) is $2 \mathrm{~nm}$. (C) Expanded area from panel B, indicated by the blue square, overlaid with an atomistic scale model with furfural in a planar geometry. (D) Model of proposed hydrogen-bonded network on the Pt(111). Adapted with permission from [172]. Copyright 2017 American Chemical Society.

As an example, the use of $\mathrm{Pt} / \mathrm{SO}_{4}-\mathrm{ZrO}_{2}$ catalyst gave rise to $47 \%$ of $\mathrm{MF}$ and $33 \%$ of furan as the main products at a temperature of $240{ }^{\circ} \mathrm{C}$ (Table 5, entry 2). Interestingly, the research of Chatterjee et al. suggested that the formation of THFA could hamperthe catalyst robustness [176]. It was, as well, demonstrated that compressed $\mathrm{CO}_{2}$ could have a synergy effect with $\mathrm{Pt}$ based catalyst and it could hinder the generation of THFA. Besides, protic solvents, especially methanol, could improve furfural conversion, but simultaneously lead to $74 \%$ selectivity to side-product-furfural dimethyl acetal. While using the same catalyst and solvent, Taylor et al. succeed in limiting the formation of this kind of side-products with a selectivity to FA higher than $97 \%$, by decreasing the reaction temperature and $\mathrm{H}_{2}$ pressure (Table 5, entry 3) [177].

One of the methods for improving the catalytic performance, depending on the employed supports, is by modifying their surfaces with different functionalities. For instance Castelbou et al. developed a new methodology for the synthesis of well-defined Pt nanoparticles that were supported on phosphine-functionalized silica [176]. The catalytic performance of the obtained material significantly improved (Table 5, entry 7). Modified carbon materials also showed an improvement on furfural selective hydrogenation $[49,176]$. For example, Liu et al. prepared porous heteroatom-doped carbon materials, as supports for Pt nanoparticles. They observed more than $99 \%$ FA yield at $100{ }^{\circ} \mathrm{C}$, and by 
performing the experiment at severe conditions, the reaction was selective towards cyclopentane via rearrangement [49]. Indeed, $\mathrm{Pt}$ supported on $\mathrm{SiO}_{2}$, without additional modification, only achieved $17 \%$ FA yield [99].

Table 5. Furfural hydrogenation over Pt-based catalysts.

\begin{tabular}{|c|c|c|c|c|c|c|c|c|c|c|c|}
\hline \multirow{2}{*}{ Entry } & \multirow{2}{*}{ Catalyst } & \multirow{2}{*}{$\begin{array}{c}\mathbf{H} \\
\text { Source }\end{array}$} & \multirow{2}{*}{ Solvent } & \multirow{2}{*}{$\begin{array}{l}\text { Temperature } \\
\left({ }^{\circ} \mathrm{C}\right)\end{array}$} & \multirow{2}{*}{$\begin{array}{l}\text { Time } \\
\text { (h) }\end{array}$} & \multirow{2}{*}{$\begin{array}{c}\text { Pressure } \\
\text { (bar) }\end{array}$} & \multicolumn{4}{|c|}{ Yield (\%) } & \multirow{2}{*}{ Ref. } \\
\hline & & & & & & & FA & MF & THFA & MTHF & \\
\hline 1 & $\mathrm{Pt} / \mathrm{Al}_{2} \mathrm{O}_{3}$ & $\mathrm{H}_{2}$ & i-PrOH & 120 & 10 & 20 & 91 & - & - & - & [165] \\
\hline 2 & $\mathrm{Pt} / \mathrm{SO}_{4}-\mathrm{ZrO}_{2}$ & $\mathrm{H}_{2}$ & i-PrOH & 240 & 8 & 20 & 4 & 47 & 0 & - & [165] \\
\hline 3 & $\mathrm{Pt} / \mathrm{Al}_{2} \mathrm{O}_{3}$ & $\mathrm{H}_{2}$ & $\mathrm{CO}_{2}$ & 80 & 4 & $90^{a}$ & 97 & - & 1 & - & [172] \\
\hline 4 & $\mathrm{Pt} / \mathrm{Al}_{2} \mathrm{O}_{3}$ & $\mathrm{H}_{2}$ & $\mathrm{MeOH}$ & 50 & 7 & 1 & 80 & - & - & - & [176] \\
\hline 5 & $\mathrm{Pt}(\mathrm{MgO})$ & $\mathrm{H}_{2}$ & $\mathrm{MeOH}$ & 50 & 7 & 1 & 77 & - & - & - & [176] \\
\hline 6 & $\mathrm{Pt} / \mathrm{P}-\mathrm{SiO}_{2}$ & $\mathrm{H}_{2}$ & Heptane & 80 & 4 & 40 & 100 & - & - & - & [177] \\
\hline 7 & $\mathrm{Pt} / \mathrm{MWNT}$ & $\mathrm{H}_{2}$ & i-PrOH & 150 & 5 & 20 & 75 & 14 & - & - & [173] \\
\hline 8 & Pt/NC-BS-500 & $\mathrm{H}_{2}$ & $\mathrm{H}_{2} \mathrm{O}$ & 100 & 4 & 10 & 99 & - & - & - & [49] \\
\hline 9 & $\mathrm{Pt} / \mathrm{SiO}_{2}$ & $\mathrm{H}_{2}$ & Toluene & 100 & 5 & 20 & 17 & - & - & - & [99] \\
\hline 10 & $\mathrm{Pt}-\mathrm{Sn} / \mathrm{SiO}_{2}$ & $\mathrm{H}_{2}$ & Toluene & 100 & 5 & 20 & 47 & - & - & - & [99] \\
\hline 11 & $\mathrm{Pt}-\mathrm{Sn} / \mathrm{SiO}_{2}$ & $\mathrm{H}_{2}$ & - & 160 & $\mathrm{~nm}$ & 1 & 97 & - & - & - & [97] \\
\hline 12 & Pt-Cu-S-PNPs & $\mathrm{H}_{2}$ & $\mathrm{MeOH}$ & 150 & 12 & 20 & 100 & - & - & - & [96] \\
\hline 13 & Pt-Fe/MWNT & $\mathrm{H}_{2}$ & $\mathrm{EtOH}$ & 100 & 5 & 30 & 87 & - & 2 & - & [94] \\
\hline 14 & Pt-Re/TiO ${ }_{2}-\mathrm{ZrO}_{2}$ & $\mathrm{H}_{2}$ & $\mathrm{EtOH}$ & 130 & 8 & 50 & 96 & - & 1 & - & [95] \\
\hline 15 & $\mathrm{Pt}-\mathrm{Co} / \mathrm{C}$ & $\mathrm{H}_{2}$ & $\mathrm{H}_{2} \mathrm{O}$ & 35 & 10 & 1 & 100 & - & - & - & [178] \\
\hline 16 & $\mathrm{Pt}-\mathrm{Co} / \mathrm{C}$ & $\mathrm{H}_{2}$ & n-PrOH & 180 & $2.5^{b}$ & 1 & 0 & 88 & - & - & [140] \\
\hline 17 & $\mathrm{Pt}-\mathrm{Co} / \mathrm{C}$ & $\mathrm{H}_{2}$ & n-PrOH & 180 & $2.5^{b}$ & 33 & 0 & 75 & - & - & [140] \\
\hline 18 & $\mathrm{Pt} / \mathrm{C}$ & $\mathrm{H}_{2}$ & СРME & 150 & $\mathrm{CF}$ & 50 & 15 & 78 & 0 & - & [141] \\
\hline
\end{tabular}

O'Driscoll found out that the incorporation of a second metal could certainly improve furfural conversion while keeping the same FA selectivity [175]. In this regard, the following order has been reported: $\mathrm{Sn}>\mathrm{Mo}>\mathrm{Mg}>\mathrm{Ba}>\mathrm{Fe}>\mathrm{Ni}$, where the best results were obtained with $\mathrm{Pt}-\mathrm{Sn} / \mathrm{SiO}_{2}$ catalyst $(47 \%$ of FA yield). Later on, by changing the $\mathrm{Pt} / \mathrm{Sn}$ ratio, an improved yield of $63 \%$ was obtained [175]. In addition, Maligal-Ganesh et al. synthesized encapsulated intermetallic $\mathrm{PtSn}_{\mathrm{mSiO}} \mathrm{manoparticle}_{2}$ catalysts while using a ship-in-a-bottle strategy [97]. In continuous regime, the catalyst exhibited the best performance with $97 \%$ FA yield as compared with its monometallic counterparts $\mathrm{Pt} @ \mathrm{mSiO}_{2}$ and by using other porous silica as support (Pt-Sn/MCF-17).

In view of the results that were obtained over Pt-based catalysts, we can draw, as a general conclusion, that this kind of catalysts preferred to hydrogenate the aldehyde group of furfural, rather than furan ring, and Pt particle size has not a big effect on the hydrogenation selectivity. The real crux of the matter is the nature of the supports, reaction conditions, as well as the incorporated metals. The continuous flow regime also resulted in a higher reaction activity and a better hydrogenation selectivity to MF.

Bimetallic catalyst Pt-Cu nanoparticles showed poor furfural conversion and FA selectivity due to the formation of furfural dimethyl acetal; however, the Pt-Cu nanoparticles with hollow-core structure exhibited over four-fold increase in catalytic activity with $100 \%$ FA selectivity, as compared to Pt-Cu nanoparticles without a hollow structure [96]. The authors proposed that aldehyde group was adsorbed into the hollow cavities ( $\mathrm{C}$ atoms of $\mathrm{C}=\mathrm{O}$ group attached to the Pt-rich outside shell and $\mathrm{O}$ atoms are proposed to occur toward the $\mathrm{Cu}$-rich inner shell), which prevented the activated $\mathrm{C}=\mathrm{O}$ bond reacting with methanol. Comparatively, the formation of furfural diethyl acetal seems to be unavoidable when other Pt based bimetallic catalysts on different supports are used [94]. Pt-Fe supported on modified multiwalled carbon nanotubes (MWNT) showed the highest FA yield of $87 \%$, but still with $5 \%$ of acetal. Chen et al. reported an improved FA yield of $96 \%$ with $3 \%$ acetal formation, using Pt-Re/TiO $-\mathrm{ZrO}_{2}$ as catalyst [95]. Impressively, $\mathrm{Pt}-\mathrm{Co} / \mathrm{C}$ bimetallic catalyst achieved $100 \%$ of FA yield at quite mild conditions (Table 5, entry 15), and $86 \%$ yield for FA was observed with concentrated furfural ( $40 \mathrm{wt} \%$ ) at $50{ }^{\circ} \mathrm{C}$ and under 10 bar of $\mathrm{H}_{2}$ pressure [178]. The catalyst characterization revealed that the presence of electron rich $\mathrm{Pt}$ and ionic Co species in proximity with each other could be correlated with the catalyst activity. Additionally, this type of catalysts possibly resulted in MF production at a higher 
temperature (Table 5, entry 16) [140]. Wang et al. observed a maximum of $88 \%$ MF yield at 1 bar of $\mathrm{H}_{2}$ flow, and a slight decrease to $75 \%$ at 33 bar of $\mathrm{H}_{2}$, due to the formation of over hydrogenated products. For comparison, our research group recently investigated the furfural selective hydrogenation to MF (78\% yield) at lower reaction temperature $\left(150{ }^{\circ} \mathrm{C}\right.$ vs $\left.180{ }^{\circ} \mathrm{C}\right)$ with monometallic catalyst $\mathrm{Pt} / \mathrm{C}$ in a continuous flow regime (Table 5, entry 18) [141].

\subsection{Ru and Other Noble Metal Based Catalysts}

In terms of MF production, non-noble metal catalysts, such as $\mathrm{Cu}$ based catalysts, seem to be more efficient than noble catalysts, but relatively harsh reaction conditions are required. Oppositely, noble metal catalysts could achieve the production of MF at mild conditions, especially in a continuous flow regime. Recently, Vlachos et al. have studied the furfural catalytic transfer hydrogenation to MF with Ru catalyst, partially forming oxide species, supported on activated carbon [101,103]. With iso-propanol as solvent, the authors obtained $61 \%$ of MF yield at $180^{\circ} \mathrm{C}$ in $10 \mathrm{~h}$, and later they improved the yield to $76 \%$ with 2-butanol or 2-pentanol as solvent. Subsequently, the mechanistic study revealed that Lewis acid-catalyzed intermolecular hydride transfer is the dominant pathway for FA formation, and further hydrogenolysis of the $\mathrm{C}-\mathrm{OH}$ bond in FA to MF mainly occurs via ring-activation involving both metal and Lewis acid sites [144]. Herein, they proved that hydrogen atom was not directly added to the carbon atom after $\mathrm{C}-\mathrm{OH}$ bond cleavage, but added to the furan ring, and followed by $\mathrm{H}$ substraction while releasing one molecule of $\mathrm{H}_{2} \mathrm{O}$. Finally, a hydrogen atom was added to the above-mentioned carbon atom (Scheme 5). Therefore, the bifunctional nature of a catalyst is critical in the efficient hydrodeoxygenation of furfural to MF. Possibly inspired by these findings, Wang et al. obtained $83 \%$ of MF yield with $\mathrm{Ru} / \mathrm{NiFeO}_{4}$ as catalyst, at similar reaction conditions [102]. Unlike the case Vlachos et al. faced, where the catalyst easily deactivated due to the $\mathrm{RuO}_{\mathrm{x}}$ reduction to metallic $\mathrm{Ru}$ during the reaction, $\mathrm{Ru} / \mathrm{NiFeO}_{4}$ showed excellent catalytic activity and recycling performance, possibly due to its relatively stable Lewis acid sites. Noticeably, relative bigger Ru particle size $(>14.1 \mathrm{~nm})$ than the values that were reported in literatures (ca. 1-4 nm) was observed [105,179,180], however, it's difficult to make a general conclusion on the influence of Ru particle size on furfural hydrogenation selectivity because of the variation of supports, surface area, reaction conditions, and even $\mathrm{Ru}$ nature $\left(\mathrm{Ru}^{0}\right.$ or $\mathrm{RuO}_{\mathrm{x}}$ ). Interestingly, Aldosari et al. found that ca. $20 \%$ of $\mathrm{MF}$ could be produced with $\mathrm{Pd}-\mathrm{Ru} / \mathrm{TiO}_{2}$ at room temperature in $2 \mathrm{~h}$, and the incorporation of $\mathrm{Ru}$ in $\mathrm{Pd} / \mathrm{TiO}_{2}$ decreased the catalytic activity but improved the selectivity towards 2-methylfuran and FA with decreased byproduct formation [105].

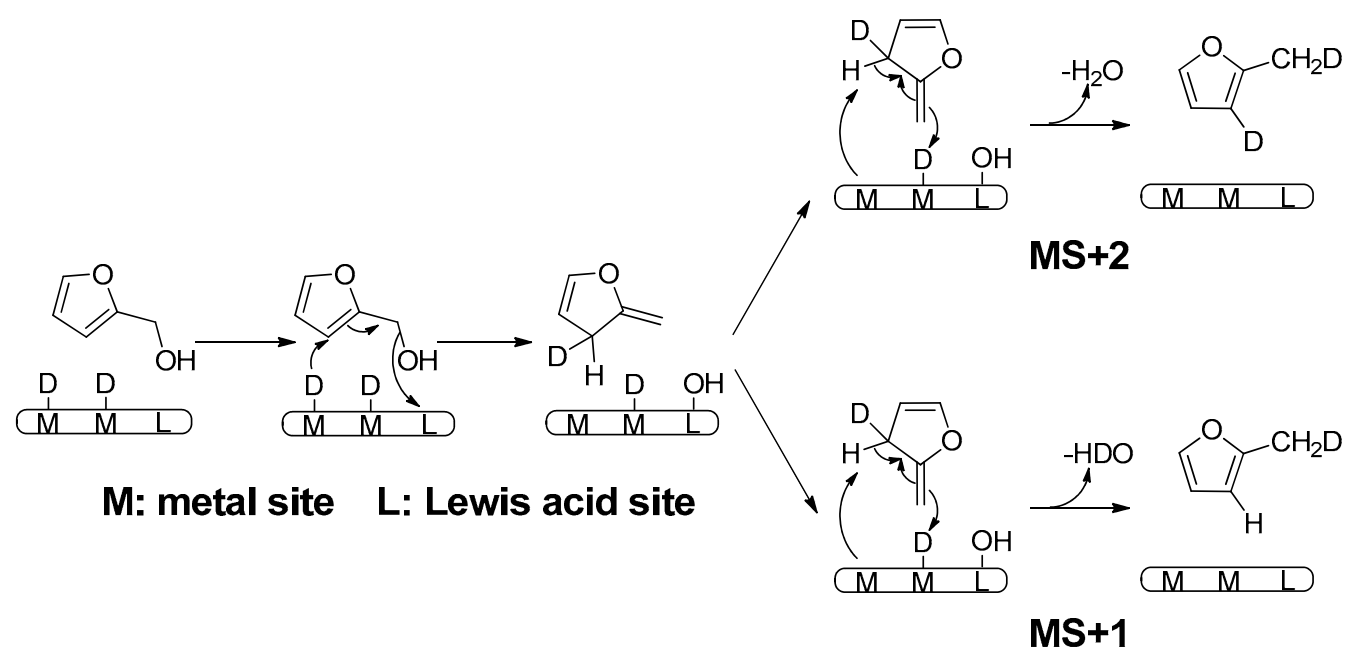

Scheme 5. Reaction mechanism for the hydrogenolysis of FA to MF over $\mathrm{Ru} / \mathrm{RuOx} / \mathrm{C}$ catalyst using isotopic lebelling. Adapted from Gilkey et al. [144]. 
With Ru based catalysts, more attention was focused on the production of FA at mild conditions. Ru supported on activated carbon, multi-wall carbon nanotubes or carbon black have been proved to be highly efficient candidates for furfural hydrogenation [84,100], but the introduction of bimetallic catalyst or other supports, such as reduced graphite or MOFs-UIO-66 and Al-MIL-53, showed outstanding improvement, and FA yields higher than $90 \%$ could be reached at $20{ }^{\circ} \mathrm{C}$ (Table 6, entries 8 and 9). Importantly, homogeneous catalyst $\mathrm{Ru} / \mathrm{Ph}_{2} \mathrm{P}\left(\mathrm{CH}_{2}\right)_{4} \mathrm{PPh}_{2}$ also showed high efficiency, since the reactions could be conducted without solvent, achieving 100\% atom economy with a high turnover frequency of $6273 \mathrm{~h}^{-1}$. Besides, the catalyst performance remained stable after twelve consecutive runs, which makes it more competitive with heterogenous catalysts. Recently, Bagnato et al. proposed an innovative ruthenium based catalytic membrane reactor [181]. Under mild conditions and low $\mathrm{H}_{2}$ loading, they obtained $26 \%$ FA yield, however the reaction turnover frequency was $48000 \mathrm{~h}^{-1}$, two orders of magnitude higher than those obtained so far. Notably, by increasing $\mathrm{H}_{2} /$ furfural molar ratio from 1:1 to $4: 1$, a $>99 \%$ selectivity to THFA was obtained under the same process conditions. Hence, $\mathrm{Ru}$ based catalysts could be potentially used to reduce $\mathrm{C}=\mathrm{C}$ bond. Huang et al. concluded that $\mathrm{Pd} / \mathrm{Al}_{2} \mathrm{O}_{3}$ catalyze preferably $\mathrm{C}=\mathrm{C}$ bond in the furan ring, while $\mathrm{Ru} / \mathrm{ZrO}_{2}$ present higher affinity with $\mathrm{C}=\mathrm{O}$ bond [33]. By combining these two catalysts physically, an unexpected $100 \%$ THFA yield was obtained at $30^{\circ} \mathrm{C}$ in $4 \mathrm{~h}$. Detailed kinetics studies suggested that firstly hydrogenation of furfural to tetrahydrofurfural over $\mathrm{Pd} / \mathrm{Al}_{2} \mathrm{O}_{3}$ and then subsequent $\mathrm{C}=\mathrm{O}$ bond hydrogenation over $\mathrm{Ru} / \mathrm{ZrO}_{2}$ will require lower activation energy, which could be directly associated with the superior activity of the mix-catalyst.

Other noble metals, such as $\mathrm{Ir}$ and $\mathrm{Au}$, have been applied for furfural hydrogenation to MF $[173,182,183]$. Selective TOF over $\mathrm{Au} / \mathrm{Al}_{2} \mathrm{O}_{3}$ (at $150{ }^{\circ} \mathrm{C}$ ) was obtained, which is significantly higher than the benchmark supported $\mathrm{Cu}$ catalysts that operated at higher temperatures $\left(180-220^{\circ} \mathrm{C}\right)$. The higher selective hydrogenation rate can be linked to the greater capacity of nano-sized Au to chemisorb/activate $\mathrm{H}_{2}$, in comparison with supported $\mathrm{Cu}$ [182]. Date et al. prepared various $\mathrm{Ir}$ supported catalysts, and reported that $\mathrm{Ir} / \mathrm{C}$ catalyst with metallic $\left(\mathrm{Ir}^{\circ}\right)$ and oxide $\left(\mathrm{IrO}_{2}\right)$ phases could give rise to $95 \%$ of MF yield at very low $\mathrm{H}_{2}$ pressure of $\sim 6.9$ bar (Table 6, entry 13). Consistent with the research of Vlachos and coworkers, who used partially oxidized ruthenium supported on carbon, Date et al. also proposed an acid mediated mechanism from furfural to MF. According to these findings, it can be concluded that acid sites on the catalyst will facilitate furfural hydrogenation to FA, and FA further hydrogenolysis to MF.

Table 6. Furfural hydrogenation over Ru-based and other catalysts.

\begin{tabular}{|c|c|c|c|c|c|c|c|c|c|c|c|}
\hline \multirow{2}{*}{ Entry } & \multirow{2}{*}{ Catalyst } & \multirow{2}{*}{$\begin{array}{c}\mathrm{H} \\
\text { Source }\end{array}$} & \multirow{2}{*}{ Solvent } & \multirow{2}{*}{$\begin{array}{c}\text { Temperature } \\
\left({ }^{\circ} \mathrm{C}\right)\end{array}$} & \multirow{2}{*}{$\begin{array}{l}\text { Time } \\
\text { (h) }\end{array}$} & \multirow{2}{*}{$\begin{array}{l}\text { Pressure } \\
\text { (bar) }\end{array}$} & \multicolumn{4}{|c|}{ Yield (\%) } & \multirow{2}{*}{ Ref. } \\
\hline & & & & & & & FA & MF & THFA & MTHF & \\
\hline 1 & $\mathrm{Ru} / \mathrm{C}$ & $\mathrm{i}-\mathrm{PrOH}$ & i-PrOH & 180 & 10 & $20.4^{a}$ & - & 61 & 0 & - & [103] \\
\hline 2 & $\mathrm{Ru}-\mathrm{RuO}_{2} / \mathrm{C}$ & 2-BuOH & 2-BuOH & 180 & 10 & $20.4^{a}$ & 7 & 76 & 1 & - & [101] \\
\hline 3 & $\mathrm{Ru} / \mathrm{NiFe}_{2} \mathrm{O}_{4}$ & i-PrOH & i-PrOH & 180 & 10 & $21^{a}$ & 1 & 83 & - & - & [102] \\
\hline 4 & $\mathrm{Pd}-\mathrm{Ru} / \mathrm{TiO}_{2}$ & $\mathrm{H}_{2}$ & octane & $\mathrm{rt}$ & 2 & 3 & 18 & 20 & 0 & - & [105] \\
\hline 5 & $\mathrm{Ru} / \mathrm{C}$ & $\mathrm{H}_{2}$ & $\mathrm{H}_{2} \mathrm{O}$ & 90 & 5 & 12.5 & 40 & - & 13 & - & [100] \\
\hline 6 & $\mathrm{Ru}-\mathrm{Sn} / \mathrm{C}$ & $\mathrm{H}_{2}$ & $\mathrm{H}_{2} \mathrm{O}$ & 90 & 5 & 12.5 & 85 & - & 1 & - & [100] \\
\hline 7 & $\mathrm{Ru} / \mathrm{rGO}$ & $\mathrm{H}_{2}$ & $\mathrm{H}_{2} \mathrm{O}$ & 20 & 4 & 10 & 91 & - & - & - & [104] \\
\hline 8 & Ru/UIO-66 & $\mathrm{H}_{2}$ & $\mathrm{H}_{2} \mathrm{O}$ & 20 & 4 & 5 & 95 & - & - & - & [179] \\
\hline 9 & Ru/Al-MIL-53 & $\mathrm{H}_{2}$ & $\mathrm{H}_{2} \mathrm{O}$ & 20 & 2 & 5 & 100 & - & - & - & [180] \\
\hline 10 & $\mathrm{Ru} / \mathrm{Ph}_{2} \mathrm{P}\left(\mathrm{CH}_{2}\right)_{4} \mathrm{PPh}_{2}$ & $\mathrm{H}_{2}$ & - & 140 & 1.3 & 25 & 100 & - & - & - & [184] \\
\hline 11 & Ru-PES membrane & $\mathrm{H}_{2}$ & $\mathrm{H}_{2} \mathrm{O}$ & 70 & $\mathrm{CF}^{b}$ & 7 & 26 & - & - & - & [178] \\
\hline 12 & $\begin{array}{l}\mathrm{Ru} / \mathrm{ZrO}_{2}+ \\
\mathrm{Pd} / \mathrm{Al}_{2} \mathrm{O}_{3}\end{array}$ & $\mathrm{H}_{2}$ & $\mathrm{H}_{2} \mathrm{O}$ & 30 & 4 & 5 & 0 & - & 100 & - & [33] \\
\hline 13 & $\mathrm{Ir} / \mathrm{C}$ & $\mathrm{H}_{2}$ & $\mathrm{i}-\mathrm{PrOH}$ & 220 & 5 & 6.9 & 0 & 95 & 1 & - & [181] \\
\hline
\end{tabular}

As for Ru-based catalysts, mild reaction conditions are better for FA production, and neutral supports seem to be preferable for the production of FA with $\mathrm{H}_{2}$ as $\mathrm{H}$ sources. Lewis acid sites from the supports or $\mathrm{Ru}$ oxides and relative higher reaction temperature both contributed to the further hydrodeoxygenation of FA to MF via catalytic transfer hydrogenation. 


\section{Conclusions and Outlook}

Through this contribution, a general vision of the advances and recent investigations in the furfural catalytic hydrogenation has been offered. Specially, we focus our attention in furfural selective hydrogenations over non-noble and noble metal heterogeneous catalysts, a topic that still have a long way to go to fully elucidate the behavior and mechanisms of the reactions, when considering the high amount of variables that determine the final product yield and distribution. Based on the researches that have been performed in the latest five years, it can be concluded that the selectivity to various furfural hydrogenation products can be achieved by (Figure 7):

(1) Control the reaction conditions, including a) temperature $\left(>200^{\circ} \mathrm{C}\right.$ benefiting to $\mathrm{MF}$ formation from furfural with $\mathrm{Cu}$ based catalysts); b) $\mathrm{H}_{2}$ pressure (high $\mathrm{H}_{2}$ pressure will lead to deep hydrogenation, even ring-opened products); c) time (deeper hydrogenation occurred by prolonging reaction time); and, d) solvents (in certain case, protic solvents leads to side-reactions) etc.

(2) Hydrogen resources. It can be noticed that transfer hydrogenation of furfural generally produce FA as product or MF under harsher conditions. Almost no THFA or MTHF is observed.

(3) Alternative active metal. For instance, $\mathrm{Cu}$ and $\mathrm{Ru}$ mainly result in hydrodeoxygenation of furfural to $\mathrm{MF}$, while $\mathrm{Co}, \mathrm{Ni}$, and Pd catalysts will lead to furan ring hydrogenation to THFA.

(4) Incorporation of different active metals. In many cases, the synergy of bimetallic catalysts showed remarkable improvement of furfural conversion and target product yield, as compared with monometallic catalysts.

(5) Alternative supports. The same metal supported on different materials could possibly give rise to different products. Especially, the acidity and basicity of the supports have significant influence on the catalytic performance of the catalyst.

(6) Alternative reaction regime. In comparison with batch reaction, continuous flow could result in enhanced productivity and sometimes the type of products varied.

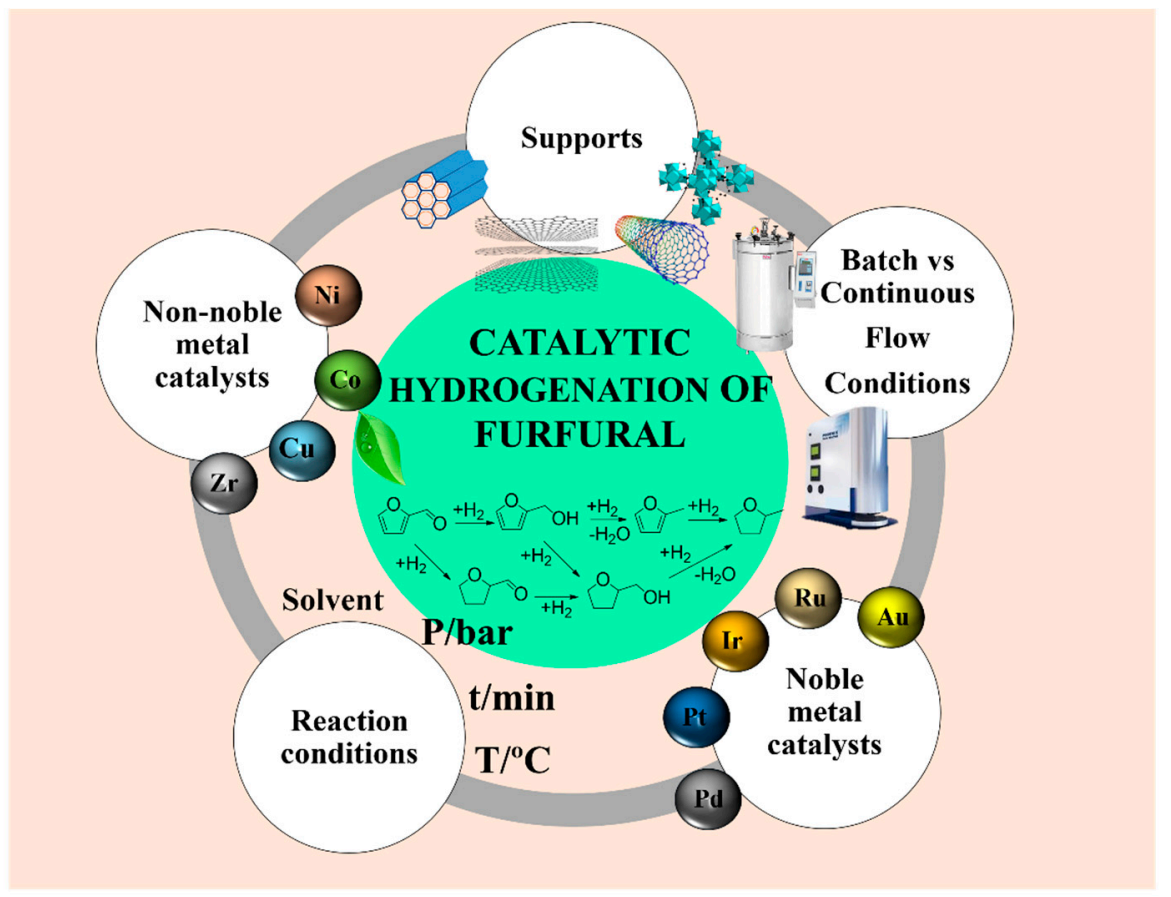

Figure 7. Representation of general factors that influence catalytic hydrogenation of furfural.

Furthermore, catalysts preparation approaches and metal reduction methods also have crucial effects on the catalytic performance of the resulting materials. In fact, these factors could complicate the analysis, which makes comparison of different catalysts not an easy task. Therefore, further efforts 
should be performed in order to find more efficient and greener methods for furfural selective transfer hydrogenation, involving non-noble metal catalysts and continuous flow regime. Although lab-scale studies employing continuous flow methodologies have been broadly described, more endeavors should be accomplished to scale-up furfural valorization through catalytic hydrogenation processes. In this regard, challenges for continuous flow technologies should be recognized, for example:

(i) Dedicated equipment is needed for precise continuous dosing (e.g., pumps), connections, etc.

(ii) Start up and shut down procedures have to be established.

(iii) Scale up of micro effects, such as the high area to volume ratio, is not possible.

(iv) Safety issues for the storage of reactive material still need to be solve.

Despite all of the progress that has been achieved so far in this area, the remarkable potential of furfural for the preparation of added-value chemicals and the possible optimization of catalytic systems and reactions conditions still lead to a broad range of possibilities. We hope that this contribution becomes an useful tool for the scientific community and that, at the same time, it can inspire researchers to keep working in this area, allowing the development of greener and more efficient process for furfural and biomass valorization.

Funding: This research received no external funding.

Acknowledgments: Yantao Wang and Deyang Zhao would like to thank the China Scholarship Council (CSC) for the financial support.

Conflicts of Interest: The authors declare no conflict of interest.

\section{References}

1. Gallezot, P. Conversion of biomass to selected chemical products. Chem. Soc. Rev. 2012, 41, 1538-1558. [CrossRef] [PubMed]

2. Kucherov, F.A.; Romashov, L.V.; Galkin, K.I.; Ananikov, V.P. Chemical transformations of biomass-derived C6-furanic platform chemicals for sustainable energy research, materials science, and synthetic building blocks. ACS Sustain. Chem. Eng. 2018, 6, 8064-8092. [CrossRef]

3. Choudhary, V.; Pinar, A.B.; Sandler, S.I.; Vlachos, D.G.; Lobo, R.F. Xylose isomerization to xylulose and its dehydration to furfural in aqueous media. ACS Catal. 2011, 1, 1724-1728. [CrossRef]

4. Hricovíniová, Z. Xylans are a valuable alternative resource: Production of D-xylose, D-lyxose and furfural under microwave irradiation. Carbohydr. Polym. 2013, 98, 1416-1421. [CrossRef] [PubMed]

5. Wang, Y.; Len, T.; Huang, Y.; Diego Taboada, A.; Boa, A.N.; Ceballos, C.; Delbecq, F.; Mackenzie, G.; Len, C. Sulfonated sporopollenin as an efficient and recyclable heterogeneous catalyst for dehydration of D-xylose and xylan into furfural. ACS Sustain. Chem. Eng. 2017, 5, 392-398. [CrossRef]

6. Rong, C.; Ding, X.; Zhu, Y.; Li, Y.; Wang, L.; Qu, Y.; Ma, X.; Wang, Z. Production of furfural from xylose at atmospheric pressure by dilute sulfuric acid and inorganic salts. Carbohydr. Res. 2012, 350, 77-80. [CrossRef] [PubMed]

7. Yang, W.; Li, P.; Bo, D.; Chang, H.; Wang, X.; Zhu, T. Optimization of furfural production from D-xylose with formic acid as catalyst in a reactive extraction system. Bioresour. Technol. 2013, 133, 361-369. [CrossRef] [PubMed]

8. Wang, S.; Zhao, Y.; Lin, H.; Chen, J.; Zhu, L.; Luo, Z. Conversion of C5 carbohydrates into furfural catalyzed by a Lewis acidic ionic liquid in renewable [gamma]-valerolactone. Green Chem. 2017, 19, 3869-3879. [CrossRef]

9. He, Y.; Pei, M.; Du, Y.; Yu, F.; Wang, L.; Guo, W. Synthesis, characterization and application of chitosan coated $\mathrm{Fe}_{3} \mathrm{O}_{4}$ particles as an adsorbent for the removal of furfural from aqueous solution. RSC Adv. 2014, 4, 30352-30357. [CrossRef]

10. Wang, Y.; Delbecq, F.; Kwapinski, W.; Len, C. Application of sulfonated carbon-based catalyst for the furfural production from D-xylose and xylan in a microwave-assisted biphasic reaction. Mol. Catal. 2017, 438, 167-172. [CrossRef]

11. Wang, S.; Zhang, Z.; Liu, B.; Li, J. Silica coated magnetic $\mathrm{Fe}_{3} \mathrm{O}_{4}$ nanoparticles supported phosphotungstic acid: A novel environmentally friendly catalyst for the synthesis of 5-ethoxymethylfurfural from 5-hydroxymethylfurfural and fructose. Catal. Sci. Technol. 2013, 3, 2104-2112. [CrossRef] 
12. Hansen, T.S.; Woodley, J.M.; Riisager, A. Efficient microwave-assisted synthesis of 5-hydroxymethylfurfural from concentrated aqueous fructose. Carbohydr. Res. 2009, 344, 2568-2572. [CrossRef] [PubMed]

13. Nikolla, E.; Román-Leshkov, Y.; Moliner, M.; Davis, M.E. “One-pot” synthesis of 5-(hydroxymethyl) furfural from carbohydrates using tin-beta zeolite. ACS Catal. 2011, 1, 408-410. [CrossRef]

14. Yong, G.; Zhang, Y.; Ying, J.Y. Efficient catalytic system for the selective production of 5-hydroxymethylfurfural from glucose and fructose. Angew. Chem. Int. Ed. 2008, 47, 9345-9348. [CrossRef] [PubMed]

15. Liu, B.; Zhang, Z.; Huang, K. Cellulose sulfuric acid as a bio-supported and recyclable solid acid catalyst for the synthesis of 5-hydroxymethylfurfural and 5-ethoxymethylfurfural from fructose. Cellulose 2013, 20, 2081-2089. [CrossRef]

16. Saravanamurugan, S.; Riisager, A. Zeolite catalyzed transformation of carbohydrates to alkyl levulinates. ChemCatChem 2013, 5, 1754-1757. [CrossRef]

17. Yadav, G.D.; Yadav, A.R. Synthesis of ethyl levulinate as fuel additives using heterogeneous solid superacidic catalysts: Efficacy and kinetic modeling. Chem. Eng. J. 2014, 243, 556-563. [CrossRef]

18. Démolis, A.; Essayem, N.; Rataboul, F. Synthesis and applications of alkyl levulinates. ACS Sustain. Chem. Eng. 2014, 2, 1338-1352. [CrossRef]

19. Antunes, M.M.; Russo, P.A.; Wiper, P.V.; Veiga, J.M.; Pillinger, M.; Mafra, L.; Evtuguin, D.V.; Pinna, N.; Valente, A.A. Sulfonated graphene oxide as effective catalyst for conversion of 5-(hydroxymethyl)-2-furfural into biofuels. ChemSusChem 2014, 7, 804-812. [CrossRef]

20. Rao, B.S.; Kumari, P.K.; Dhanalakshmi, D.; Lingaiah, N. Selective conversion of furfuryl alcohol into butyl levulinate over zinc exchanged heteropoly tungstate supported on niobia catalysts. J. Mol. Catal. Chem. 2016, 427, 80-86. [CrossRef]

21. Mandalika, A.; Qin, L.; Sato, T.K.; Runge, T. Integrated Biorefinery Model Based on Production of Furans Using Open-Ended High Yield Processes. Green Chem. 2014, 16, 2480-2489. [CrossRef]

22. Vaidya, P.D.; Mahajani, V.V. Kinetics of liquid-phase hydrogenation of furfuraldehyde to furfuryl alcohol over a Pt/C Catalyst. Ind. Eng. Chem. Res. 2003, 42, 3881-3885. [CrossRef]

23. Sitthisa, S.; Sooknoi, T.; Ma, Y.; Balbuena, P.B.; Resasco, D.E. Kinetics and mechanism of hydrogenation of furfural on $\mathrm{Cu} / \mathrm{SiO}_{2}$ catalysts. J. Catal. 2011, 277, 1-13. [CrossRef]

24. Yan, K.; Chen, A. Efficient hydrogenation of biomass-derived furfural and levulinic acid on the facilely synthesized noble-metal-free Cu-Cr catalyst. Energy 2013, 58, 357-363. [CrossRef]

25. Yan, K.; Chen, A. Selective hydrogenation of furfural and levulinic acid to biofuels on the ecofriendly $\mathrm{Cu}-\mathrm{Fe}$ catalyst. Fuel 2014, 115, 101-108. [CrossRef]

26. Sato, S.; Igarashi, J.; Yamada, Y. Stable vapor-phase conversion of tetrahydrofurfuryl alcohol into 3, 4-2H-dihydropyran. Appl. Catal. A 2013, 453, 213-218. [CrossRef]

27. Choi, J.H.; Lee, W.Y. Pyridine synthesis from tetrahydrofurfuryl alcohol over a $\mathrm{Pd} / \gamma-\mathrm{Al}_{2} \mathrm{O}_{3}$ catalyst: II. Effect of supports and palladium loading. Appl. Catal. A 1993, 98, 21-31. [CrossRef]

28. Koso, S.; Watanabe, H.; Okumura, K.; Nakagawa, Y.; Tomishige, K. Comparative study of Rh-MoOx and Rh-ReOx supported on $\mathrm{SiO}_{2}$ for the hydrogenolysis of ethers and polyols. Appl. Catal. B 2012, 111, 27-37. [CrossRef]

29. Chia, M.; Pagán-Torres, Y.J.; Hibbitts, D.; Tan, Q.; Pham, H.N.; Datye, A.K.; Neurock, M.; Davis, R.J.; Dumesic, J.A. Selective hydrogenolysis of polyols and cyclic ethers over bifunctional surface sites on rhodium-rhenium catalysts. J. Am. Chem. Soc. 2011, 133, 12675-12689. [CrossRef]

30. Koso, S.; Furikado, I.; Shimao, A.; Miyazawa, T.; Kunimori, K.; Tomishige, K. Chemoselective hydrogenolysis of tetrahydrofurfuryl alcohol to 1,5-pentanediol. Chem. Commun. 2009, 15, 2035-2037. [CrossRef]

31. Pace, V.; Hoyos, P.; Castoldi, L.; Dominguez de Maria, P.; Alcantara, A.R. 2-Methyltetrahydrofuran (2-MeTHF): A biomass-derived solvent with broad application in organic chemistry. ChemSusChem 2012, 5, 1369-1379. [CrossRef]

32. Yang, J.; Li, S.; Zhang, L.; Liu, X.; Wang, J.; Pan, X.; Li, N.; Wang, A.; Cong, Y.; Wang, X.; et al. Hydrodeoxygenation of furans over $\mathrm{Pd}-\mathrm{FeO}_{\mathrm{x}} / \mathrm{SiO}_{2}$ catalyst under atmospheric pressure. Appl. Catal. B 2017, 201, 266-277. [CrossRef]

33. Huang, R.; Cui, Q.; Yuan, Q.; Wu, H.; Guan, Y.; Wu, P. Total hydrogenation of furfural over $\mathrm{Pd} / \mathrm{Al}_{2} \mathrm{O}_{3}$ and $\mathrm{Ru} / \mathrm{ZrO}_{2}$ mixture under mild conditions: Essential role of tetrahydrofurfural as an intermediate and support effect. ACS Sustain. Chem. Eng. 2018, 6, 6957-6964. [CrossRef] 
34. Hu, Q.; Fan, G.; Yang, L.; Cao, X.; Zhang, P.; Wang, B.; Li, F. A gas-phase coupling process for simultaneous production of $\gamma$-butyrolactone and furfuryl alcohol without external hydrogen over bifunctional base-metal heterogeneous catalysts. Green Chem. 2016, 18, 2317-2322. [CrossRef]

35. Winoto, H.P.; Fikri, Z.A.; Ha, J.M.; Park, Y.K.; Lee, H.; Suh, D.J.; Jae, J. Heteropolyacid supported on Zr-beta zeolite as an active catalyst for one-pot transformation of furfural to $\gamma$-valerolactone. Appl. Catal. B 2019, 241, 588-597. [CrossRef]

36. Li, X.; Lan, X.; Wang, T. Highly selective catalytic conversion of furfural to $\gamma$-butyrolactone. Green Chem. 2016, 18, 638-642. [CrossRef]

37. Winoto, H.P.; Ahn, B.S.; Jae, J. Production of $\gamma$-valerolactone from furfural by a single-step process using Sn-Al-Beta zeolites: Optimizing the catalyst acid properties and process conditions. J. Ind. Eng. Chem. 2016, 40, 62-71. [CrossRef]

38. Chen, B.; Li, F.; Huang, Z.; Yuan, G. Hydrogen-transfer conversion of furfural into levulinate esters as potential biofuel feedstock. J. Energy Chem. 2016, 25, 888-894. [CrossRef]

39. Zhu, S.; Cen, Y.; Guo, J.; Chai, J.; Wang, J.; Fan, W. One-pot conversion of furfural to alkyl levulinate over bifunctional Au- $\mathrm{H}_{4} \mathrm{SiW}_{12} \mathrm{O}_{40} / \mathrm{ZrO}_{2}$ without external $\mathrm{H}_{2}$. Green Chem. 2016, 18, 5667-5675. [CrossRef]

40. Hronec, M.; Fulajtárová, K.; Vávra, I.; Soták, T.; Dobročka, E.; Mičušík, M. Carbon supported Pd-Cu catalysts for highly selective rearrangement of furfural to cyclopentanone. Appl. Catal. B 2016,181, 210-219. [CrossRef]

41. Wang, Y.; Sang, S.; Zhu, W.; Gao, L.; Xiao, G. CuNi@C catalysts with high activity derived from metal-organic frameworks precursor for conversion of furfural to cyclopentanone. Chem. Eng. J. 2016, 299, $104-111$. [CrossRef]

42. Xu, Y.J.; Shi, J.; Wu, W.P.; Zhu, R.; Li, X.L.; Deng, J.; Fu, Y. Effect of Cp*iridium(III) complex and acid co-catalyst on conversion of furfural compounds to cyclopentanones or straight chain ketones. Appl. Catal. A 2017, 543, 266-273. [CrossRef]

43. Fang, R.; Liu, H.; Luque, R.; Li, Y. Efficient and selective hydrogenation of biomass-derived furfural to cyclopentanone using Ru catalysts. Green Chem. 2015, 17, 4183-4188. [CrossRef]

44. Zhang, Y.; Fan, G.; Yang, L.; Li, F. Efficient conversion of furfural into cyclopentanone over high performing and stable $\mathrm{Cu} / \mathrm{ZrO}_{2}$ catalysts. Appl. Catal. A 2018, 561, 117-126. [CrossRef]

45. Dohade, M.; Dhepe, P.L. Efficient method for cyclopentanone synthesis from furfural: Understanding the role of solvents and solubility in a bimetallic catalytic system. Catal. Sci. Technol. 2018, 8, 5259-5269. [CrossRef]

46. Li, X.L.; Deng, J.; Shi, J.; Pan, T.; Yu, C.G.; Xu, H.J.; Fu, Y. Selective conversion of furfural to cyclopentanone or cyclopentanol using different preparation methods of Cu-Co catalysts. Green Chem. 2015, 17, 1038-1046. [CrossRef]

47. Zhou, M.; Li, J.; Wang, K.; Xia, H.; Xu, J.; Jiang, J. Selective conversion of furfural to cyclopentanone over CNT-supported Cu based catalysts: Model reaction for upgrading of bio-oil. Fuel 2017, 202, 1-11. [CrossRef]

48. Zhang, G.S.; Zhu, M.M.; Zhang, Q.; Liu, Y.M.; He, H.Y.; Cao, Y. Towards quantitative and scalable transformation of furfural to cyclopentanone with supported gold catalysts. Green Chem. 2016, 18, $2155-2164$. [CrossRef]

49. Liu, X.; Zhang, B.; Fei, B.; Chen, X.; Zhang, J.; Mu, X. Tunable and selective hydrogenation of furfural to furfuryl alcohol and cyclopentanone over Pt supported on biomass-derived porous heteroatom doped carbon. Faraday Discuss. 2017, 202, 79-98. [CrossRef]

50. Zhou, M.; Zeng, Z.; Zhu, H.; Xiao, G.; Xiao, R. Aqueous-phase catalytic hydrogenation of furfural to cyclopentanol over $\mathrm{Cu}-\mathrm{Mg}-\mathrm{Al}$ hydrotalcites derived catalysts: Model reaction for upgrading of bio-oil. J. Energy Chem. 2014, 23, 91-96. [CrossRef]

51. Ma, Y.F.; Wang, H.; Xu, G.Y.; Liu, X.H.; Zhang, Y.; Fu, Y. Selective conversion of furfural to cyclopentanol over cobalt catalysts in one step. Chin. Chem. Lett. 2017, 28, 1153-1158. [CrossRef]

52. Date, N.S.; Chikate, R.C.; Roh, H.S.; Rode, C.V. Bifunctional role of Pd/MMT-K 10 catalyst in direct transformation of furfural to 1,2-pentanediol. Catal. Today 2018, 309, 195-201. [CrossRef]

53. Liu, F.; Liu, Q.; Xu, J.; Li, L.; Cui, Y.T.; Lang, R.; Li, L.; Su, Y.; Miao, S.; Sun, H.; et al. Catalytic cascade conversion of furfural to 1,4-pentanediol in a single reactor. Green Chem. 2018, 20, 1770-1776. [CrossRef]

54. Liu, S.; Amada, Y.; Tamura, M.; Nakagawa, Y.; Tomishige, K. Performance and characterization of rhenium-modified Rh-Ir alloy catalyst for one-pot conversion of furfural into 1,5-pentanediol. Catal. Sci. Technol. 2014, 4, 2535-2549. [CrossRef] 
55. Li, F.; Lu, T.; Chen, B.; Huang, Z.; Yuan, G. Pt nanoparticles over $\mathrm{TiO}_{2}-\mathrm{ZrO}_{2}$ mixed oxide as multifunctional catalysts for an integrated conversion of furfural to 1,4-butanediol. Appl. Catal. A 2014, 478, 252-258. [CrossRef]

56. Ruifeng, L.; Hongxia, Z.; Xiaoyu, L.; Jinhe, S.; Dan, W.; Shumei, Z. Research progress on catalysts for hydrogenation of furfural to furfural alcohol. Refin. Chem. Ind. 2010, 5, 6-8. [CrossRef]

57. Wu, J.; Shen, Y.M.; Liu, C.H.; Zhang, Z.X. Progress of Catalysts for Hydrogenation of Furfural to Produce Furfuryl Alcohol and 2-methylfuran. Modern Chemical Industry 2002, S1, 18-28. [CrossRef]

58. Yan, K.; Wu, G.; Lafleur, T.; Jarvis, C. Production, properties and catalytic hydrogenation of furfural to fuel additives and value-added chemicals. Renew. Sustain. Energy Rev. 2014, 38, 663-676. [CrossRef]

59. Romano, P.N.; de Almeida, J.M.A.R.; Carvalho, Y.; Priecel, P.; Falabella Sousa-Aguiar, E.; Lopez-Sanchez, J.A. Back cover: Microwave-assisted selective hydrogenation of furfural to furfuryl alcohol employing a green and noble metal-free copper catalyst. ChemSusChem 2016, 9, 3528. [CrossRef]

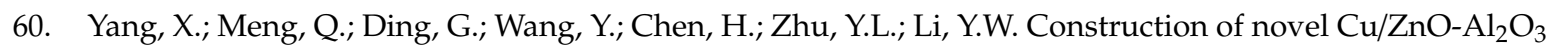
composites for furfural hydrogenation: The Role of Al components. Appl. Catal. A 2018, 561, 78-86. [CrossRef]

61. Dong, F.; Zhu, Y.; Zheng, H.; Zhu, Y.; Li, X.; Li, Y. Cr-free Cu-catalysts for the selective hydrogenation of biomass-derived furfural to 2-methylfuran: The synergistic effect of metal and acid sites. J. Mol. Catal. Chem. 2015, 398, 140-148. [CrossRef]

62. Chen, H.; Ruan, H.; Lu, X.; Fu, J.; Langrish, T.; Lu, X. Efficient catalytic transfer hydrogenation of furfural to furfuryl alcohol in near-critical isopropanol over $\mathrm{Cu} / \mathrm{MgO}-\mathrm{Al}_{2} \mathrm{O}_{3}$ catalyst. Mol. Catal. 2018, 445, 94-101. [CrossRef]

63. Vargas-Hernández, D.; Rubio-Caballero, J.M.; Santamaría-González, J.; Moreno-Tost, R.; Mérida-Robles, J.M.; Pérez-Cruz, M.A.; Jiménez-López, A.; Hernández-Huesca, R.; Maireles-Torres, P. Furfuryl alcohol from furfural hydrogenation over copper supported on SBA-15 silica catalysts. J. Mol. Catal. Chem. 2014, 383-384, 106-113. [CrossRef]

64. Jiménez-Gómez, C.P.; Cecilia, J.A.; Márquez-Rodríguez, I.; Moreno-Tost, R.; Santamaría-González, J.; Mérida-Robles, J.; Maireles-Torres, P. Gas-phase hydrogenation of furfural over $\mathrm{Cu} / \mathrm{CeO}_{2}$ catalysts. Catal. Today 2017, 279, 327-338. [CrossRef]

65. Yang, X.; Chen, H.; Meng, Q.; Zheng, H.; Zhu, Y.; Li, Y.W. Insights into influence of nanoparticle size and metal-support interactions of $\mathrm{Cu} / \mathrm{ZnO}$ catalysts on activity for furfural hydrogenation. Catal. Sci. Technol. 2017, 7, 5625-5634. [CrossRef]

66. Villaverde, M.M.; Garetto, T.F.; Marchi, A.J. Liquid-phase transfer hydrogenation of furfural to furfuryl alcohol on $\mathrm{Cu}-\mathrm{Mg}-\mathrm{Al}$ catalysts. Catal. Commun. 2015, 58, 6-10. [CrossRef]

67. Romano, P.N.; de Almeida, J.M.A.R.; Carvalho, Y.; Priecel, P.; Falabella Sousa-Aguiar, E.; Lopez-Sanchez, J.A. Microwave-assisted selective hydrogenation of furfural to furfuryl alcohol employing a green and noble metal-free copper catalyst. ChemSusChem 2016, 9, 3387-3392. [CrossRef]

68. Dong, F.; Zhu, Y.; Zhao, H.; Tang, Z. Ratio-controlled synthesis of phyllosilicate-like materials as precursors for highly efficient catalysis of the formyl group. Catal. Sci. Technol. 2017, 7, 1880-1891. [CrossRef]

69. Wang, Y.; Zhu, W.; Sang, S.; Gao, L.; Xiao, G. Supported Cu catalysts for the hydrogenation of furfural in aqueous phase: Effect of support. Asia-Pac. J. Chem. Eng. 2017, 12, 422-431. [CrossRef]

70. Su, Y.; Chen, C.; Zhu, X.; Zhang, Y.; Gong, W.; Zhang, H.; Zhao, H.; Wang, G. Carbon-embedded Ni nanocatalysts derived from MOFs by a sacrificial template method for efficient hydrogenation of furfural to tetrahydrofurfuryl alcohol. Dalton Trans. 2017, 46, 6358-6365. [CrossRef]

71. Yang, Y.; Ma, J.; Jia, X.; Du, Z.; Duan, Y.; Xu, J. Aqueous phase hydrogenation of furfural to tetrahydrofurfuryl alcohol on alkaline earth metal modified $\mathrm{Ni} / \mathrm{Al}_{2} \mathrm{O}_{3}$. RSC Adv. 2016, 6, 51221-51228. [CrossRef]

72. Jia, P.; Lan, X.; Li, X.; Wang, T. Highly active and selective $\mathrm{NiFe} / \mathrm{SiO}_{2}$ bimetallic catalyst with optimized solvent effect for the liquid-phase hydrogenation of furfural to furfuryl alcohol. ACS Sustain. Chem. Eng. 2018, 6, 13287-13295. [CrossRef]

73. Gong, W.; Chen, C.; Zhang, H.; Wang, G.; Zhao, H. Highly dispersed Co and Ni nanoparticles encapsulated in $\mathrm{N}$-doped carbon nanotubes as efficient catalysts for the reduction of unsaturated oxygen compounds in aqueous phase. Catal. Sci. Technol. 2018, 8, 5506-5514. [CrossRef] 
74. Kotbagi, T.V.; Gurav, H.R.; Nagpure, A.S.; Chilukuri, S.V.; Bakker, M.G. Highly efficient nitrogen-doped hierarchically porous carbon supported Ni nanoparticles for the selective hydrogenation of furfural to furfuryl alcohol. RSC Adv. 2016, 6, 67662-67668. [CrossRef]

75. Xu, Y.; Qiu, S.; Long, J.; Wang, C.; Chang, J.; Tan, J.; Liu, Q.; Ma, L.; Wang, T.; Zhang, Q. In situ hydrogenation of furfural with additives over a RaneyßNi catalyst. RSC Adv. 2015, 5, 91190-91195. [CrossRef]

76. Astuti, M.D.; Mujiyanti, D.R.; Santoso, U.T.; Shimazu, S. Novel preparation method of bimetallic Ni-In alloy catalysts supported on amorphous alumina for the highly selective hydrogenation of furfural. Mol. Catal. 2018, 445, 52-60. [CrossRef]

77. Manikandan, M.; Venugopal, A.K.; Prabu, K.; Jha, R.K.; Thirumalaiswamy, R. Role of surface synergistic effect on the performance of Ni-based hydrotalcite catalyst for highly efficient hydrogenation of furfural. J. Mol. Catal. Chem. 2016, 417, 153-162. [CrossRef]

78. Jeong, H.; Kim, C.; Yang, S.; Lee, H. Selective hydrogenation of furanic aldehydes using Ni nanoparticle catalysts capped with organic molecules. J. Catal. 2016, 344, 609-615. [CrossRef]

79. Liu, L.; Lou, H.; Chen, M. Selective hydrogenation of furfural to tetrahydrofurfuryl alcohol over Ni/CNTs and bimetallic CuNi/CNTs catalysts. Int. J. Hydrog. Energy 2016, 41, 14721-14731. [CrossRef]

80. Gong, W.; Chen, C.; Wang, H.; Fan, R.; Zhang, H.; Wang, G.; Zhao, H. Sulfonate group modified Ni catalyst for highly efficient liquid-phase selective hydrogenation of bio-derived furfural. Chin. Chem. Lett. 2018, 29, 1617-1620. [CrossRef]

81. Srivastava, S.; Jadeja, G.C.; Parikh, J. Copper-cobalt catalyzed liquid phase hydrogenation of furfural to 2-methylfuran: An optimization, kinetics and reaction mechanism study. Chem. Eng. Res. Des. 2018, 132, 313-324. [CrossRef]

82. Jiang, P.; Li, X.; Gao, W.; Wang, X.; Tang, Y.; Lan, K.; Wang, B.; Li, R. Highly selective hydrogenation of $\alpha, \beta$-unsaturated carbonyl compounds over supported Co nanoparticles. Catal. Commun. 2018, 111, 6-9. [CrossRef]

83. Garcia-Olmo, A.J.; Yepez, A.; Balu, A.M.; Romero, A.A.; Li, Y.; Luque, R. Insights into the activity, selectivity and stability of heterogeneous catalysts in the continuous flow hydroconversion of furfural. Catal. Sci. Technol. 2016, 6, 4705-4711. [CrossRef]

84. Mironenko, R.M.; Belskaya, O.B.; Gulyaeva, T.I.; Nizovskii, A.I.; Kalinkin, A.V.; Bukhtiyarov, V.I.; Lavrenov, A.V.; Likholobov, V.A. Effect of the nature of carbon support on the formation of active sites in $\mathrm{Pd} / \mathrm{C}$ and $\mathrm{Ru} / \mathrm{C}$ catalysts for hydrogenation of furfural. Catal. Today 2015, 249, 145-152. [CrossRef]

85. Pang, S.H.; Schoenbaum, C.A.; Schwartz, D.K.; Medlin, J.W. Effects of thiol modifiers on the kinetics of furfural hydrogenation over Pd catalysts. ACS Catal. 2014, 4, 3123-3131. [CrossRef]

86. Wang, Y.; Cui, Q.; Guan, Y.; Wu, P. Facile synthesis of furfuryl ethyl ether in high yield via the reductive etherification of furfural in ethanol over Pd/C under mild conditions. Green Chem. 2018, 20, 2110-2117. [CrossRef]

87. Nanao, H.; Murakami, Y.; Sato, O.; Yamaguchi, A.; Hiyoshi, N.; Shirai, M. Furfuryl alcohol and furfural hydrogenation over activated carbon-supported palladium catalyst in presence of water and carbon dioxide. ChemistrySelect 2017, 2, 2471-2475. [CrossRef]

88. Yin, D.; Ren, H.; Li, C.; Liu, J.; Liang, C. Highly selective hydrogenation of furfural to tetrahydrofurfuryl alcohol over MIL-101(Cr)-NH2 supported Pd catalyst at low temperature. Chin. J. Catal. 2018, 39, 319-326. [CrossRef]

89. Li, C.; Xu, G.; Liu, X.; Zhang, Y.; Fu, Y. Hydrogenation of biomass-derived furfural to tetrahydrofurfuryl alcohol over hydroxyapatite-supported Pd catalyst under mild conditions. Ind. Eng. Chem. Res. 2017, 56, 8843-8849. [CrossRef]

90. Nguyen-Huy, C.; Kim, J.S.; Yoon, S.; Yang, E.; Kwak, J.H.; Lee, M.S.; An, K. Supported Pd nanoparticle catalysts with high activities and selectivities in liquid-phase furfural hydrogenation. Fuel 2018, 226, 607-617. [CrossRef]

91. Albilali, R.; Douthwaite, M.; He, Q.; Taylor, S.H. The selective hydrogenation of furfural over supported palladium nanoparticle catalysts prepared by sol-immobilisation: Effect of catalyst support and reaction conditions. Catal. Sci. Technol. 2018, 8, 252-267. [CrossRef]

92. Ouyang, W.; Yepez, A.; Romero, A.A.; Luque, R. Towards industrial furfural conversion: Selectivity and stability of palladium and platinum catalysts under continuous flow regime. Catal. Today 2018, 308, 32-37. [CrossRef] 
93. Nishimura, S.; Shimura, T.; Ebitani, K. Transfer hydrogenation of furaldehydes with sodium phosphinate as a hydrogen source using Pd-supported alumina catalyst. J. Taiwan Inst. Chem. Eng. 2017, 79, 97-102. [CrossRef]

94. Liu, L.; Lou, H.; Chen, M. Selective hydrogenation of furfural over Pt based and Pd based bimetallic catalysts supported on modified multiwalled carbon nanotubes (MWNT). Appl. Catal. A 2018, 550, 1-10. [CrossRef]

95. Chen, B.; Li, F.; Huang, Z.; Yuan, G. Tuning catalytic selectivity of liquid-phase hydrogenation of furfural via synergistic effects of supported bimetallic catalysts. Appl. Catal. A 2015, 500, 23-29. [CrossRef]

96. Huang, S.; Yang, N.; Wang, S.; Sun, Y.; Zhu, Y. Tuning the synthesis of platinum-copper nanoparticles with a hollow core and porous shell for the selective hydrogenation of furfural to furfuryl alcohol. Nanoscale 2016, 8, 14104-14108. [CrossRef]

97. Maligal-Ganesh, R.V.; Xiao, C.; Goh, T.W.; Wang, L.L.; Gustafson, J.; Pei, Y.; Qi, Z.; Johnson, D.D.; Zhang, S.; Tao, F.; et al. A ship-in-a-bottle strategy to synthesize encapsulated intermetallic nanoparticle catalysts: Exemplified for furfural hydrogenation. ACS Catal. 2016, 6, 1754-1763. [CrossRef]

98. Zhang, C.; Lai, Q.; Holles, J.H. Bimetallic overlayer catalysts with high selectivity and reactivity for furfural hydrogenation. Catal. Commun. 2017, 89, 77-80. [CrossRef]

99. O'Driscoll, Á.; Leahy, J.J.; Curtin, T. The influence of metal selection on catalyst activity for the liquid phase hydrogenation of furfural to furfuryl alcohol. Catal. Today 2017, 279, 194-201. [CrossRef]

100. Musci, J.J.; Merlo, A.B.; Casella, M.L. Aqueous phase hydrogenation of furfural using carbon-supported Ru and RuSn catalysts. Catal. Today 2017, 296, 43-50. [CrossRef]

101. Panagiotopoulou, P.; Martin, N.; Vlachos, D.G. Effect of hydrogen donor on liquid phase catalytic transfer hydrogenation of furfural over a $\mathrm{Ru} / \mathrm{RuO}_{2} / \mathrm{C}$ catalyst. J. Mol. Catal. Chem. 2014, 392, 223-228. [CrossRef]

102. Wang, B.; Li, C.; He, B.; Qi, J.; Liang, C. Highly stable and selective $\mathrm{Ru} / \mathrm{NiFe}_{2} \mathrm{O}_{4}$ catalysts for transfer hydrogenation of biomass-derived furfural to 2-methylfuran. J. Energy Chem. 2017, 26, 799-807. [CrossRef]

103. Panagiotopoulou, P.; Vlachos, D.G. Liquid phase catalytic transfer hydrogenation of furfural over a Ru/C catalyst. Appl. Catal. A 2014, 480, 17-24. [CrossRef]

104. Ramirez-Barria, C.; Isaacs, M.; Wilson, K.; Guerrero-Ruiz, A.; Rodríguez-Ramos, I. Optimization of ruthenium based catalysts for the aqueous phase hydrogenation of furfural to furfuryl alcohol. Appl. Catal. A 2018, 563, 177-184. [CrossRef]

105. Aldosari, O.F.; Iqbal, S.; Miedziak, P.J.; Brett, G.L.; Jones, D.R.; Liu, X.; Edwards, J.K.; Morgan, D.J.; Knight, D.K.; Hutchings, G.J. Pd-Ru/TiO 2 catalyst-An active and selective catalyst for furfural hydrogenation. Catal. Sci. Technol. 2015, 6, 234-242. [CrossRef]

106. Yan, Y.; Bu, C.; He, Q.; Zheng, Z.; Ouyang, J. Efficient bioconversion of furfural to furfuryl alcohol by Bacillus Coagulans NL01. RSC Adv. 2018, 8, 26720-26727. [CrossRef]

107. He, Y.; Ding, Y.; Ma, C.; Di, J.; Jiang, C.; Li, A. One-pot conversion of biomass-derived xylose to furfuralcohol by a chemo-enzymatic sequential acid-catalyzed dehydration and bioreduction. Green Chem. 2017, 19, 3844-3850. [CrossRef]

108. Jung, S.; Biddinger, E.J. Electrocatalytic hydrogenation and hydrogenolysis of furfural and the impact of homogeneous side reactions of furanic compounds in acidic electrolytes. ACS Sustain. Chem. Eng. 2016, 4, 6500-6508. [CrossRef]

109. Zhao, B.; Chen, M.; Guo, Q.; Fu, Y. Electrocatalytic hydrogenation of furfural to furfuryl alcohol using platinum supported on activated carbon fibers. Electrochim. Acta 2014, 135, 139-146. [CrossRef]

110. Jung, S.; Karaiskakis, A.N.; Biddinger, E.J. Enhanced activity for electrochemical hydrogenation and hydrogenolysis of furfural to biofuel using electrodeposited Cu catalysts. Catal. Today 2019, 323, 26-34. [CrossRef]

111. Liu, L.; Liu, H.; Huang, W.; He, Y.; Zhang, W.; Wang, C.; Lin, H. Mechanism and kinetics of the electrocatalytic hydrogenation of furfural to furfuryl alcohol. J. Electroanal. Chem. 2017, 804, 248-253. [CrossRef]

112. Chadderdon, X.H.; Chadderdon, D.J.; Matthiesen, J.E.; Qiu, Y.; Carraher, J.M.; Tessonnier, J.P.; Li, W. Mechanisms of furfural reduction on metal electrodes: Distinguishing pathways for selective hydrogenation of bioderived oxygenates. J. Am. Chem. Soc. 2017, 139, 14120-14128. [CrossRef]

113. Gaillard, S.; Renaud, J.L. Iron-catalyzed hydrogenation, hydride transfer, and hydrosilylation: An alternative to precious-metal complexes? ChemSusChem 2008, 1, 505-509. [CrossRef] 
114. Filonenko, G.A.; van Putten, R.; Hensen, E.J.M.; Pidko, E.A. Catalytic (de)hydrogenation promoted by non-precious metals-Co, Fe and Mn: Recent advances in an emerging field. Chem. Soc. Rev. 2018, 47, 1459-1483. [CrossRef]

115. Ryabchuk, P.; Agostini, G.; Pohl, M.M.; Lund, H.; Agapova, A.; Junge, H.; Junge, K.; Beller, M. Intermetallic nickel silicide nanocatalyst-A non-noble metal-based general hydrogenation catalyst. Sci. Adv. 2018, 4. [CrossRef]

116. Liu, L.; Concepción, P.; Corma, A. Non-noble metal catalysts for hydrogenation: A facile method for preparing Co nanoparticles covered with thin layered carbon. J. Catal. 2016, 340, 1-9. [CrossRef]

117. Sun, J.; Yu, J.; Ma, Q.; Meng, F.; Wei, X.; Sun, Y.; Tsubaki, N. Freezing Copper as a Noble Metal-like Catalyst for Preliminary Hydrogenation. Sci. Adv. 2018, 4. [CrossRef]

118. Sun, C.; Zeng, P.; He, M.; He, X.; Xie, X. Morphological effect of non-supported copper nanocrystals on furfural hydrogenation. Catal. Commun. 2016, 86, 5-8. [CrossRef]

119. Gong, W.; Chen, C.; Fan, R.; Zhang, H.; Wang, G.; Zhao, H. Transfer-hydrogenation of furfural and levulinic acid over supported copper catalyst. Fuel 2018, 231, 165-171. [CrossRef]

120. Zhang, H.; Lei, Y.; Kropf, A.J.; Zhang, G.; Elam, J.W.; Miller, J.T.; Sollberger, F.; Ribeiro, F.; Akatay, M.C.; Stach, E.A.; et al. Enhancing the stability of copper chromite catalysts for the selective hydrogenation of furfural using ALD overcoating. J. Catal. 2014, 317, 284-292. [CrossRef]

121. Prakruthi, H.R.; Chandrashekara, B.M.; Jai, P.B.S.; Bhat, Y.S. Hydrogenation efficiency of highly porous $\mathrm{Cu}-\mathrm{Al}$ oxides derived from dealuminated LDH in the conversion of furfural to furfuryl alcohol. J. Ind. Eng. Chem. 2018, 62, 96-105. [CrossRef]

122. Jiménez-Gómez, C.P.; Cecilia, J.A.; Durán-Martín, D.; Moreno-Tost, R.; Santamaría-González, J.; Mérida-Robles, J.; Mariscal, R.; Maireles-Torres, P. Gas-phase hydrogenation of furfural to furfuryl alcohol over $\mathrm{Cu} / \mathrm{ZnO}$ catalysts. J. Catal. 2016, 336, 107-115. [CrossRef]

123. Jiménez-Gómez, C.P.; Cecilia, J.A.; Franco-Duro, F.I.; Pozo, M.; Moreno-Tost, R.; Maireles-Torres, P. Promotion effect of Ce or $\mathrm{Zn}$ oxides for improving furfuryl alcohol yield in the furfural hydrogenation using inexpensive Cu-Based catalysts. Mol. Catal. 2018, 455, 121-131. [CrossRef]

124. Jackson, M.A.; White, M.G.; Haasch, R.T.; Peterson, S.C.; Blackburn, J.A. Hydrogenation of furfural at the dynamic $\mathrm{Cu}$ surface of $\mathrm{CuOCeO}_{2} / \mathrm{Al}_{2} \mathrm{O}_{3}$ in a vapor phase packed bed reactor. Mol. Catal. 2018, 445, 124-132. [CrossRef]

125. Srivastava, S.; Mohanty, P.; Parikh, J.K.; Dalai, A.K.; Amritphale, S.S.; Khare, A.K. Cr-Free Co-Cu/SBA-15 catalysts for hydrogenation of biomass-derived $\alpha$-, $\beta$-unsaturated aldehyde to alcohol. Chin. J. Catal. 2015, 36, 933-942. [CrossRef]

126. Srivastava, S.; Jadeja, G.C.; Parikh, J. A versatile Bi-metallic copper-cobalt catalyst for liquid phase hydrogenation of furfural to 2-methylfuran. RSC Adv. 2015, 6, 1649-1658. [CrossRef]

127. Dong, F.; Ding, G.; Zheng, H.; Xiang, X.; Chen, L.; Zhu, Y.; Li, Y. Highly dispersed Cu nanoparticles as an efficient catalyst for the synthesis of the biofuel 2-methylfuran. Catal. Sci. Technol. 2016, 6, 767-779. [CrossRef]

128. Gong, W.; Chen, C.; Zhang, H.; Wang, G.; Zhao, H. In situ synthesis of highly dispersed Cu-Co bimetallic nanoparticles for tandem hydrogenation/rearrangement of bioderived furfural in aqueous-phase. ACS Sustain. Chem. Eng. 2018, 6, 14919-14925. [CrossRef]

129. Wang, Y.; Miao, Y.; Li, S.; Gao, L.; Xiao, G. Metal-organic frameworks derived bimetallic Cu-Co catalyst for efficient and selective hydrogenation of biomass-derived furfural to furfuryl alcohol. Mol. Catal. 2017, 436, 128-137. [CrossRef]

130. Zhang, Z.; Pei, Z.; Chen, H.; Chen, K.; Hou, Z.; Lu, X.; Ouyang, P.; Fu, J. Catalytic in-situ hydrogenation of furfural over bimetallic Cu-Ni alloy catalysts in isopropanol. Ind. Eng. Chem. Res. 2018, 57, 4225-4230. [CrossRef]

131. Srivastava, S.; Jadeja, G.C.; Parikh, J. Synergism studies on alumina-supported copper-nickel catalysts towards furfural and 5-hydroxymethylfurfural hydrogenation. J. Mol. Catal. Chem. 2017, 426, 244-256. [CrossRef]

132. Pang, S.H.; Love, N.E.; Medlin, J.W. Synergistic effects of alloying and thiolate modification in furfural hydrogenation over Cu-based catalysts. J. Phys. Chem. Lett. 2014, 5, 4110-4114. [CrossRef]

133. Fu, Z.; Wang, Z.; Lin, W.; Song, W.; Li, S. High efficient conversion of furfural to 2-methylfuran over $\mathrm{Ni}-\mathrm{Cu} / \mathrm{Al}_{2} \mathrm{O}_{3}$ catalyst with formic acid as a hydrogen donor. Appl. Catal. A 2017, 547, 248-255. [CrossRef] 
134. Wu, J.; Gao, G.; Li, J.; Sun, P.; Long, X.; Li, F. Efficient and versatile CuNi alloy nanocatalysts for the highly selective hydrogenation of furfural. Appl. Catal. B 2017, 203, 227-236. [CrossRef]

135. Zhang, J.; Chen, J. Selective transfer hydrogenation of biomass-based furfural and 5-hydroxymethylfurfural over hydrotalcite-derived copper catalysts using methanol as a hydrogen donor. ACS Sustain. Chem. Eng. 2017, 5, 5982-5993. [CrossRef]

136. Manikandan, M.; Venugopal, A.K.; Nagpure, A.S.; Chilukuri, S.; Raja, T. Promotional effect of Fe on the performance of supported Cu catalyst for ambient pressure hydrogenation of furfural. RSC Adv. 2016, 6, 3888-3898. [CrossRef]

137. Audemar, M.; Ciotonea, C.; De Oliveira Vigier, K.; Royer, S.; Ungureanu, A.; Dragoi, B.; Dumitriu, E.; Jérôme, F. Selective hydrogenation of furfural to furfuryl alcohol in the presence of a recyclable cobalt/SBA-15 catalyst. ChemSusChem 2015, 8, 1885-1891. [CrossRef]

138. Lee, J.; Burt, S.P.; Carrero, C.A.; Alba-Rubio, A.C.; Ro, I.; O’Neill, B.J.; Kim, H.J.; Jackson, D.H.; Kuech, T.F.; Hermans, I. Stabilizing cobalt catalysts for aqueous-phase reactions by strong metal-support interaction. J. Catal. 2015, 330, 19-27. [CrossRef]

139. Sulmonetti, T.P.; Pang, S.H.; Claure, M.T.; Lee, S.; Cullen, D.A.; Agrawal, P.K.; Jones, C.W. Vapor phase hydrogenation of furfural over nickel mixed metal oxide catalysts derived from layered double hydroxides. Appl. Catal. A 2016, 517, 187-195. [CrossRef]

140. Wang, C.; Luo, J.; Liao, V.; Lee, J.D.; Onn, T.M.; Murray, C.B.; Gorte, R.J. A comparison of furfural hydrodeoxygenation over Pt-Co and Ni-Fe catalysts at high and low $\mathrm{H}_{2}$ pressures. Catal. Today 2018, 302, 73-79. [CrossRef]

141. Wang, Y.; Prinsen, P.; Triantafyllidis, K.S.; Karakoulia, S.A.; Trikalitis, P.N.; Yepez, A.; Len, C.; Luque, R. Comparative study of supported monometallic catalysts in the liquid-phase hydrogenation of furfural: Batch versus continuous flow. ACS Sustain. Chem. Eng. 2018, 6, 9831-9844. [CrossRef]

142. Wang, Y.; Prinsen, P.; Triantafyllidis, K.S.; Karakoulia, S.A.; Yepez, A.; Len, C.; Luque, R. Batch versus continuous flow performance of supported mono- and bimetallic nickel catalysts for catalytic transfer hydrogenation of furfural in isopropanol. ChemCatChem 2018, 10, 3459-3468. [CrossRef]

143. Koehle, M.; Lobo, R.F. Lewis Acidic Zeolite Beta Catalyst for the Meerwein-Ponndorf-Verley Reduction of Furfural. Catal. Sci. Technol. 2016, 6, 3018-3026. [CrossRef]

144. Gilkey, M.J.; Panagiotopoulou, P.; Mironenko, A.V.; Jenness, G.R.; Vlachos, D.G.; Xu, B. Mechanistic insights into metal Lewis acid-mediated catalytic transfer hydrogenation of furfural to 2-methylfuran. ACS Catal. 2015, 5, 3988-3994. [CrossRef]

145. He, J.; Yang, S.; Riisager, A. Magnetic nickel ferrite nanoparticles as highly durable catalysts for catalytic transfer hydrogenation of bio-based aldehydes. Catal. Sci. Technol. 2018, 8, 790-797. [CrossRef]

146. Li, S.; Wang, Y.; Gao, L.; Wu, Y.; Yang, X.; Sheng, P.; Xiao, G. Short channeled Ni-Co/SBA-15 catalysts for highly selective hydrogenation of biomass-derived furfural to tetrahydrofurfuryl alcohol. Micropor. Mesopor. Mater. 2018, 262, 154-165. [CrossRef]

147. Marakatti, V.S.; Arora, N.; Rai, S.; Sarma, S.C.; Peter, S.C. Understanding the role of atomic ordering in the crystal structures of NixSny toward efficient vapor phase furfural hydrogenation. ACS Sustain. Chem. Eng. 2018, 6, 7325-7338. [CrossRef]

148. Astuti, M.D.; Santoso, U.T.; Shimazu, S. Hydrogenation of biomass-derived furfural over highly dispersed-aluminium hydroxide supported Ni-Sn(3.0) alloy catalysts. Procedia Chem. 2015, 16, 531-539. [CrossRef]

149. Montes, V.; Miñambres, J.F.; Khalilov, A.N.; Boutonnet, M.; Marinas, J.M.; Urbano, F.J.; Maharramov, A.M.; Marinas, A. Chemoselective hydrogenation of furfural to furfuryl alcohol on $\mathrm{ZrO}_{2}$ systems synthesized through the microemulsion method. Catal. Today 2018, 306, 89-95. [CrossRef]

150. Zhang, J.; Dong, K.; Luo, W.; Guan, H. Selective transfer hydrogenation of furfural into furfuryl alcohol on Zr-containing catalysts using lower alcohols as hydrogen donors. ACS Omega 2018, 3, 6206-6216. [CrossRef]

151. Sha, Y.; Xiao, Z.; Zhou, H.; Yang, K.; Song, Y.; Li, N.; He, R.; Zhi, K.; Liu, Q. Direct use of humic acid mixtures to construct efficient Zr-containing catalysts for Meerwein-Ponndorf-Verley reactions. Green Chem. 2017, 19, 4829-4837. [CrossRef]

152. Li, H.; Li, Y.; Fang, Z.; Smith, R.L. Efficient catalytic transfer hydrogenation of biomass-based furfural to furfuryl alcohol with recycable Hf-phenylphosphonate nanohybrids. Catal. Today 2019, 319, 84-92. [CrossRef] 
153. Injongkol, Y.; Maihom, T.; Treesukul, P.; Sirijaraensre, J.; Boekfa, B.; Limtrakul, J. Theoretical study on the reaction mechanism of hydrogenation of furfural to furfuryl alcohol on Lewis acidic BEA zeolites: Effects of defect structure and tetravalent metals substitution. Phys. Chem. Chem. Phys. 2017, 19, 24042-24048. [CrossRef]

154. Kim, M.S.; Simanjuntak, F.S.H.; Lim, S.; Jae, J.; Ha, J.M.; Lee, H. Synthesis of alumina-carbon composite material for the catalytic conversion of furfural to furfuryl alcohol. J. Ind. Eng. Chem. 2017, 52, 59-65. [CrossRef]

155. Xie, L.; Chen, T.; Chan, H.C.; Shu, Y.; Gao, Q. Front cover: Hydrogen doping into $\mathrm{MoO}_{3}$ supports toward modulated metal-support interactions and efficient furfural hydrogenation on iridium nanocatalysts. Chem. Asian J. 2018, 13, 584. [CrossRef]

156. Zhang, Z.; Tong, X.; Zhang, H.; Li, Y. Versatile catalysis of iron: Tunable and selective transformation of biomass-derived furfural in aliphatic alcohol. Green Chem. 2018, 20, 3092-3100. [CrossRef]

157. Lee, W.S.; Wang, Z.; Zheng, W.; Vlachos, D.G.; Bhan, A. Vapor phase hydrodeoxygenation of furfural to 2-methylfuran on molybdenum carbide catalysts. Catal. Sci. Technol. 2014, 4, 2340-2352. [CrossRef]

158. Grazia, L.; Bonincontro, D.; Lolli, A.; Tabanelli, T.; Lucarelli, C.; Albonetti, S.; Cavani, F. Exploiting H-transfer as a tool for the catalytic reduction of bio-based building blocks: The gas-phase production of 2-methylfurfural using a $\mathrm{FeVO}_{4}$ catalyst. Green Chem. 2017, 19, 4412-4422. [CrossRef]

159. Wu, W.; Zhao, W.; Fang, C.; Wang, Z.; Yang, T.; Li, H.; Yang, S. Quantitative hydrogenation of furfural to furfuryl alcohol with recyclable KF and hydrosilane at room temperature in minutes. Catal. Commun. 2018, 105, 6-10. [CrossRef]

160. Grazia, L.; Lolli, A.; Folco, F.; Zhang, Y.; Albonetti, S.; Cavani, F. Gas-phase cascade upgrading of furfural to 2-methylfuran using methanol as a $\mathrm{H}$-transfer reactant and $\mathrm{MgO}$ based catalysts. Catal. Sci. Technol. 2016, 6, 4418-4427. [CrossRef]

161. Garcia-Olmo, A.J.; Yepez, A.; Balu, A.M.; Prinsen, P.; Garcia, A.; Maziere, A.; Len, C.; Luque, R. Activity of continuous flow synthesized Pd-based nanocatalysts in the flow hydroconversion of furfural. Tetrahedron 2017, 73, 5599-5604. [CrossRef]

162. Vorotnikov, V.; Mpourmpakis, G.; Vlachos, D.G. DFT study of furfural conversion to furan, furfuryl alcohol, and 2-methylfuran on Pd(111). ACS Catal. 2012, 2, 2496-2504. [CrossRef]

163. Hu, X.; Kadarwati, S.; Song, Y.; Li, C.Z. Simultaneous hydrogenation and acid-catalyzed conversion of the biomass-derived furans in solvents with distinct polarities. RSC Adv. 2016, 6, 4647-4656. [CrossRef]

164. Casoni, A.I.; Hoch, P.M.; Volpe, M.A.; Gutierrez, V.S. Catalytic conversion of furfural from pyrolysis of sunflower seed hulls for producing bio-based furfuryl alcohol. J. Clean. Prod. 2018, 178, 237-246. [CrossRef]

165. Bhogeswararao, S.; Srinivas, D. Catalytic conversion of furfural to industrial chemicals over supported Pt and Pd catalysts. J. Catal. 2015, 327, 65-77. [CrossRef]

166. Lesiak, M.; Binczarski, M.; Karski, S.; Maniukiewicz, W.; Rogowski, J.; Szubiakiewicz, E.; Berlowska, J.; Dziugan, P.; Witońska, I. Hydrogenation of furfural over $\mathrm{Pd}-\mathrm{Cu} / \mathrm{Al}_{2} \mathrm{O}_{3}$ catalysts. The role of interaction between palladium and copper on determining catalytic properties. J. Mol. Catal. Chem. 2014, 395, 337-348. [CrossRef]

167. Date, N.S.; Biradar, N.S.; Chikate, R.C.; Rode, C.V. Effect of reduction protocol of Pd catalysts on product distribution in furfural hydrogenation. ChemistrySelect 2017, 2, 24-32. [CrossRef]

168. Pino, N.; Sitthisa, S.; Tan, Q.; Souza, T.; López, D.; Resasco, D.E. Structure, activity, and selectivity of bimetallic $\mathrm{Pd}-\mathrm{Fe} / \mathrm{SiO}_{2}$ and $\mathrm{Pd}-\mathrm{Fe} / \gamma-\mathrm{Al}_{2} \mathrm{O}_{3}$ catalysts for the conversion of furfural. J. Catal. 2017, 350, 30-40. [CrossRef]

169. Fulajtárova, K.; Soták, T.; Hronec, M.; Vávra, I.; Dobročka, E.; Omastová, M. Aqueous phase hydrogenation of furfural to furfuryl alcohol over Pd-Cu catalysts. Appl. Catal. A 2015, 502, 78-85. [CrossRef]

170. Du, J.; Zhang, J.; Sun, Y.; Jia, W.; Si, Z.; Gao, H.; Tang, X.; Zeng, X.; Lei, T.; Liu, S.; et al. Catalytic transfer hydrogenation of biomass-derived furfural to furfuryl alcohol over in-situ prepared nano $\mathrm{Cu}-\mathrm{Pd} / \mathrm{C}$ catalyst using formic acid as hydrogen source. J. Catal. 2018, 368, 69-78. [CrossRef]

171. Puthiaraj, P.; Kim, K.; Ahn, W.S. Catalytic transfer hydrogenation of bio-based furfural by palladium supported on nitrogen-doped porous carbon. Catal. Today 2019, 324, 49-58. [CrossRef]

172. Taylor, M.J.; Jiang, L.; Reichert, J.; Papageorgiou, A.C.; Beaumont, S.K.; Wilson, K.; Kyriakou, G. Catalytic hydrogenation and hydrodeoxygenation of furfural over $\mathrm{Pt}$ (111): A model system for the rational design and operation of practical biomass conversion catalysts. J. Phys. Chem. C 2017, 121, 8490-8497. [CrossRef] 
173. Castelbou, J.L.; Szeto, K.C.; Barakat, W.; Merle, N.; Godard, C.; Taoufik, M.; Claver, C. A new approach for the preparation of well-defined $\mathrm{Rh}$ and $\mathrm{Pt}$ nanoparticles stabilized by phosphine-functionalized silica for selective hydrogenation reactions. Chem. Commun. 2017, 53, 3261-3264. [CrossRef]

174. Wang, C.; Guo, Z.; Yang, Y.; Chang, J.; Borgna, A. Hydrogenation of furfural as model reaction of bio-oil stabilization under mild conditions using multiwalled carbon nanotube (MWNT)-supported Pt catalysts. Ind. Eng. Chem. Res. 2014, 53, 11284-11291. [CrossRef]

175. O’Driscoll, Á.; Curtin, T.; Hernández, W.Y.; Van Der Voort, P.; Leahy, J.J. Hydrogenation of furfural with a Pt-Sn catalyst: The suitability to sustainable industrial application. Org. Process Res. Dev. 2016, 20, 1917-1929. [CrossRef]

176. Chatterjee, M.; Chatterjee, A.; Ishizaka, T.; Kawanami, H. Defining Pt-compressed $\mathrm{CO}_{2}$ synergy for selectivity control of furfural hydrogenation. RSC Adv. 2018, 8, 20190-20201. [CrossRef]

177. Taylor, M.J.; Durndell, L.J.; Isaacs, M.A.; Parlett, C.M.A.; Wilson, K.; Lee, A.F.; Kyriakou, G. Highly selective hydrogenation of furfural over supported Pt nanoparticles under mild conditions. Appl. Catal. B 2016, 180, 580-585. [CrossRef]

178. Dohade, M.G.; Dhepe, P.L. Efficient hydrogenation of concentrated aqueous furfural solutions into furfuryl alcohol under ambient conditions in presence of PtCo bimetallic catalyst. Green Chem. 2017, 19, 1144-1154. [CrossRef]

179. Yuan, Q.; Zhang, D.; van Haandel, L.; Ye, F.; Xue, T.; Hensen, E.J.M.; Guan, Y. Selective liquid phase hydrogenation of furfural to furfuryl alcohol by Ru/Zr-MOFs. J. Mol. Catal. Chem. 2015, 406, 58-64. [CrossRef]

180. Yang, J.; Ma, J.; Yuan, Q.; Zhang, P.; Guan, Y. Selective hydrogenation of furfural on Ru/Al-MIL-53: A comparative study on the effect of aromatic and aliphatic organic linkers. RSC Adv. 2016, 6, 92299-92304. [CrossRef]

181. Bagnato, G.; Figoli, A.; Ursino, C.; Galiano, F.; Sanna, A. A Novel Ru-polyethersulfone (PES) catalytic membrane for highly efficient and selective hydrogenation of furfural to furfuryl alcohol. J. Mater. Chem. A 2018, 6, 4955-4965. [CrossRef]

182. Date, N.S.; Hengne, A.M.; Huang, K.W.; Chikate, R.C.; Rode, C.V. Single Pot selective hydrogenation of furfural to 2-methylfuran over carbon supported iridium catalysts. Green Chem. 2018, 20, 2027-2037. [CrossRef]

183. Li, M.; Hao, Y.; Cárdenas-Lizana, F.; Keane, M.A. Selective production of furfuryl alcohol via gas phase hydrogenation of furfural over $\mathrm{Au} / \mathrm{Al}_{2} \mathrm{O}_{3}$. Catal. Commun. 2015, 69, 119-122. [CrossRef]

184. Tukacs, J.M.; Bohus, M.; Dibó, G.; Mika, L.T. Ruthenium-catalyzed solvent-free conversion of furfural to furfuryl alcohol. RSC Adv. 2017, 7, 3331-3335. [CrossRef] 